\title{
Surveying, Interpreting, and Designing: The Multiple Essence of a Sixteenth-Century Drawing
}

\author{
LUCIA NUTI \\ University of Pisa
}

$\mathrm{D}$ uring the last quarter of the fifteenth century the practice of drawing, already long in existence among architects, underwent a radical evolution that influenced the whole process of artistic creation. Drawing was developing as a medium for architectural communication in the widest sense, but it was still free from the codification that would subsequently regulate its practice.

To examine an early sixteenth-century architectural drawing is to penetrate the artist's intellectual world and follow the development of an individual conception of architecture along with a mode of representation. With varying graphic languages and in no preestablished order, the artist could use a single sheet to fix disparate subjects that were relevant in different ways to his involvement in architecture. Drawings and sketches thus constitute valuable resources for architectural research, expressing architects' individual experiences as they occurred in the field. Nevertheless, these materials have not usually been studied from this point of view, as was the case with the drawing I will consider in this essay.

The item marked $7950 \mathrm{~A}$ in the inventory of the Gabinetto Disegni e Stampe of the Uffizi in Florence is a large parchment sheet measuring 1,350 by $1,665 \mathrm{~mm}$, composed of smaller and irregular sheets pasted together (Figure 1). It is an unfinished drawing of the city of Pisa, labeled on the back "pisa no finjtta" (Pisa unfinished). The final $a$ and the following "di [by] Giuliano da Sangallo" were added later by a different hand, in a different ink. ${ }^{1}$ Unknown to the public

Journal of the Society of Architectural Historians 75, no. 1 (March 2016), 5-24. ISSN 0037-9808, electronic ISSN 2150-5926. (C) 2016 by the Society of Architectural Historians. All rights reserved. Please direct all requests for permission to photocopy or reproduce article content through the University of California Press's Reprints and Permissions web page, http://www.ucpress.edu/ journals.php?p=reprints, or via email: jpermissions@ucpress.edu. DOI: 10.1525/ jsah.2016.75.1.5. until the early twentieth century, the drawing has not yet received proper scholarly attention, despite its being referenced in a long list of titles. ${ }^{2}$ On one hand, architectural historians have too hastily dismissed the drawing as a work of minor, local interest and so have never analyzed it deeply; on the other, local historians have conducted only narrow investigations concerned mainly with queries about urban topography, a field in which the drawing has proved to be very unreliable.

Despite the uneven attention it has received, this graphic document proves to be extremely significant and worthy of detailed examination for a number of reasons. First, it is one of the earliest Renaissance depictions of a city in orthogonal outline that also includes depictions of buildings and architectural details in orthogonal outline. It is a surviving witness of the rediscovered conceptual attitude toward town representation in which abstract spatial relations were given priority at the expense of visual appearance: a highly sophisticated representational mode that soon became the most practiced among architects and engineers but remained less popular with the wider public. The current literature refers to the drawing superficially as a pianta, a measured ground plan, but what can actually be read in it is both much less and much more than the information contained in a survey. The drawing raises important questions that pass beyond the mode of representation and concern the meaning and the use of drawing among architects in the early sixteenth century, casting a new light on that period. Furthermore, the inscription on the back introduces the name of Giuliano da Sangallo, who was one of the leading figures of the early Italian Renaissance. Giuliano trained as a woodworker in Florence with his brother Antonio and moved to Rome around 1465. While dwelling in Rome for long periods, he was involved in various papal projects and played a leading role in the 


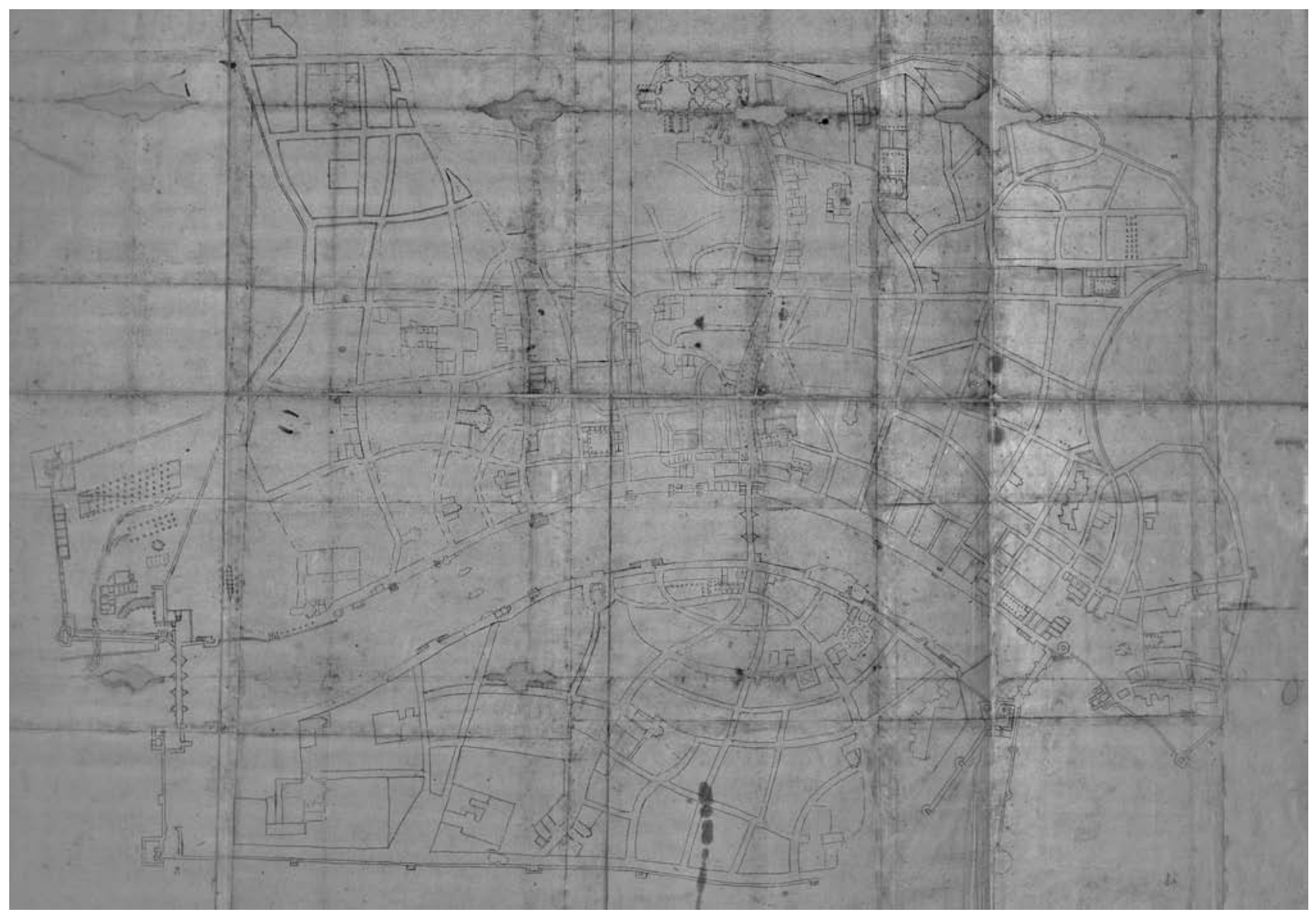

Figure 1 Giuliano da Sangallo, "Pisa Unfinished" (Gabinetto Disegni e Stampe, 7950 A, Uffizi, Florence; by permission of the Ministero dei Beni e delle Attività Culturali e del Turismo, Italy; any reproduction prohibited).

architectural renewal, interpreting and spreading the revival of interest in classical antiquity. ${ }^{3}$

My discussion of the Uffizi drawing is articulated in two parts. First, I try to address the questions of dating and authorship, which remain unsettled, since any further consideration of the drawing depends on their resolution. Second, I examine the drawing thoroughly to reveal as far as possible its extremely complex nature and to investigate how it contributes to our knowledge of its author's persona and the practice of architectural drawing in the early Renaissance.

\section{Dating and Authorship}

The problems of dating and authorship, which must be settled first, are magnified by a specific feature of the drawing: two different outlines are clearly distinguishable on it. The first, a dotted outline in charcoal, still visible although almost worn away, is the result of a transfer by pouncing. The second outline, in sanguigna (reddish) ink, introduced some additions not present in the charcoal line, and it does not follow the charcoal completely. The draftsman who used the pen abandoned the tracing and left his work unfinished for some unknown reason, providing no indications of measurements, no decoration, and no inscriptions. The drawing's "unfinished" status can also be understood from the fact that different types of pen lines-single, double, and broken lines-are used in overwriting the charcoal dots, apparently as marks for different stages of the author's work. ${ }^{4}$

The question of dating seems not to have troubled previous scholars, and the only discussion that tackles it closely, by Emilio Tolaini, is spoiled by a basic flaw: the unexplained assumption that the two outlines are not contemporary and do not belong to the same hand. ${ }^{5}$ Tolaini maintains that the author of the pen outline copied an earlier, existing survey, in a manner he describes as sloppy. Although the practice of reusing previous surveys was common at the time and also in later centuries, a close inspection of the Uffizi drawing reveals that no time gap seems to occur between the two outlines, since the only detail allowing us to attempt a dating, the depiction of a work that was then in progress in Pisa, is rendered in the same way in both outlines. ${ }^{6}$

The new Florentine fortress in the southeast section of the city is represented in the drawing as incomplete, and a 
full understanding of the importance of this detail depends on knowledge of the events that occurred in Pisa from the end of the fifteenth century through the early sixteenth century. In 1495 a rebellion against the Florentines broke out in Pisa; the wall of the old Florentine fortress facing the town was pulled down, and the hated Florentine rulers were kicked out. In 1509 the Florentine government sent Giuliano da Sangallo and his brother Antonio to the front against Pisa as military engineers. According to Vasari, Giuliano contributed to the fall of the city, building a pontoon bridge across the river Arno. ${ }^{7}$ Immediately after reconquering the city in 1509 , the Florentines were concerned with restoring the damaged shell of the fort and building a new, stronger fortress on and around the old one to protect their garrison properly and prevent future rebellions. ${ }^{8} \mathrm{On}$ 13 August of the same year, Giuliano is recorded as traveling from Florence to Pisa, where he was officially credited as chief architect of the new fortress, apparently taking over from Antonio, who had been sent to the city in that role earlier. ${ }^{9}$ Many documents attest to Giuliano's presence in Pisa until 31 March 1512, the date of the last record, after which he left the town once and for all. ${ }^{10} \mathrm{He}$ moved to Rome, where Giovanni de' Medici had been elected Pope Leo X. The reasons for Giuliano's departure are not specified in the records. Apparently, he was not dismissed by the Florentine government. We can only assume that, given his poor relations with Florence, the expectation of a prestigious task at the papal court might have provoked his voluntary abandonment of the work in Pisa.

Returning to the depiction of the fortress in the drawing, if we consider that the west bastion overlooking the river and the bridge, although partially effaced by a tear in the sheet, is correctly rendered in charcoal and in pen, we can assume that both outlines can be dated to 1511 , the year of the bastion's actual construction. ${ }^{11}$ The pen line was, therefore, going over a pattern that had already been updated to reflect the military works being constructed in the recaptured city, and I believe it is quite reasonable to conclude that the author was overwriting a previous product of his own (Figure 2).

The issue of authorship revolves around the same fortress. Most scholars have commonly considered Giuliano's work on the building of the fortress and his familiarity with the city between 1509 and 1512 as sufficient reasons to accept the posthumous attribution to Giuliano without any discussion. Tolaini rejects Giuliano's authorship based only on the argument that the survey of the city was so coarse and imprecise that it could not be considered the work of such a master. ${ }^{12}$

Since no direct document has yet emerged from the archives on the subject, it is worth considering a number of arguments that indirectly reinforce the case for Giuliano's authorship. Two of these relate to the "unfinished" status of the drawing. Coming back again to the two outlines, the ink overwriting is interrupted twice, around the new fortress and around the cathedral square. The fact that the buildings included in these areas- the fortress, the cathedral, the baptistery, and the Leaning Tower-are the only ones that boast separate sketches in one of Giuliano's sketchbooks, the Taccuino senese, immediately implies a connection between the two (see Figure 2) $\cdot{ }^{13}$ It is reasonable to conclude that Giuliano might have thought of transferring the results of his own detailed surveys to the sheet at a second time. When he left Pisa, with no prospect of coming back, his interest in completing the drawing might have vanished.

In the area of the cathedral square there is no pen line at all, and the charcoal dots are too faded to be compared with Giuliano's sketches. As for the new fortress, its ink delineation was started and two sides of the triangle are completethat is, the portion that had actually been built first. A comparison of this incomplete outline with the finished sketch in the Taccuino senese, which shows a more ambitious solution that was not realized, suggests a connection between the drawing and the sketch. Despite the inferior quality and the roughness of the survey drawing, the portion of the walls and the elements already built, along with the feeble charcoal traces of the internal structures and some anticipations of what was unbuilt, seem to follow the pattern of the sketch in the Taccuino. The bastion at the end of the eastern curtain wall on the river past the old tower, which is depicted in the Taccuino, is not represented in the drawing, but a circle marks the area of the sand bank that was supposed to surround the bastion. ${ }^{14}$ The author reveals a personal, precise knowledge of the work in progress and a technical eye, also shown in his minute rendering of the old citadel at the opposite side of the town; this fortress was no longer used for defense purposes but was still regarded as a military area, and not everyone had direct access to it (Figure 3). ${ }^{15}$

Beyond the evidence of the drawing, another indirect argument in favor of Giuliano's authorship comes from a consideration of the way this large, fragile sheet survived and came to us. In the documents concerning Giuliano's three years of activity in Pisa there is no mention of a survey commissioned by the Florentine government, or of additional jobs assigned to the architect in the town. In fact, there would have been no need to survey the whole town, since the new fortress had to be built on and around the previous one. The fact that there is no documentary mention of a survey commissioned from Giuliano by the Florentine government does not mean that there could not have been one. The drawing itself, however, refutes the hypothesis that it was composed for a public purpose. The document was not kept in the archives of a public office, as was usual with topographical records, but was part of a miscellaneous collection privately owned by the Sangallo family and was possibly used as studio material. ${ }^{16}$ Giorgio Vasari purchased the whole collection, 

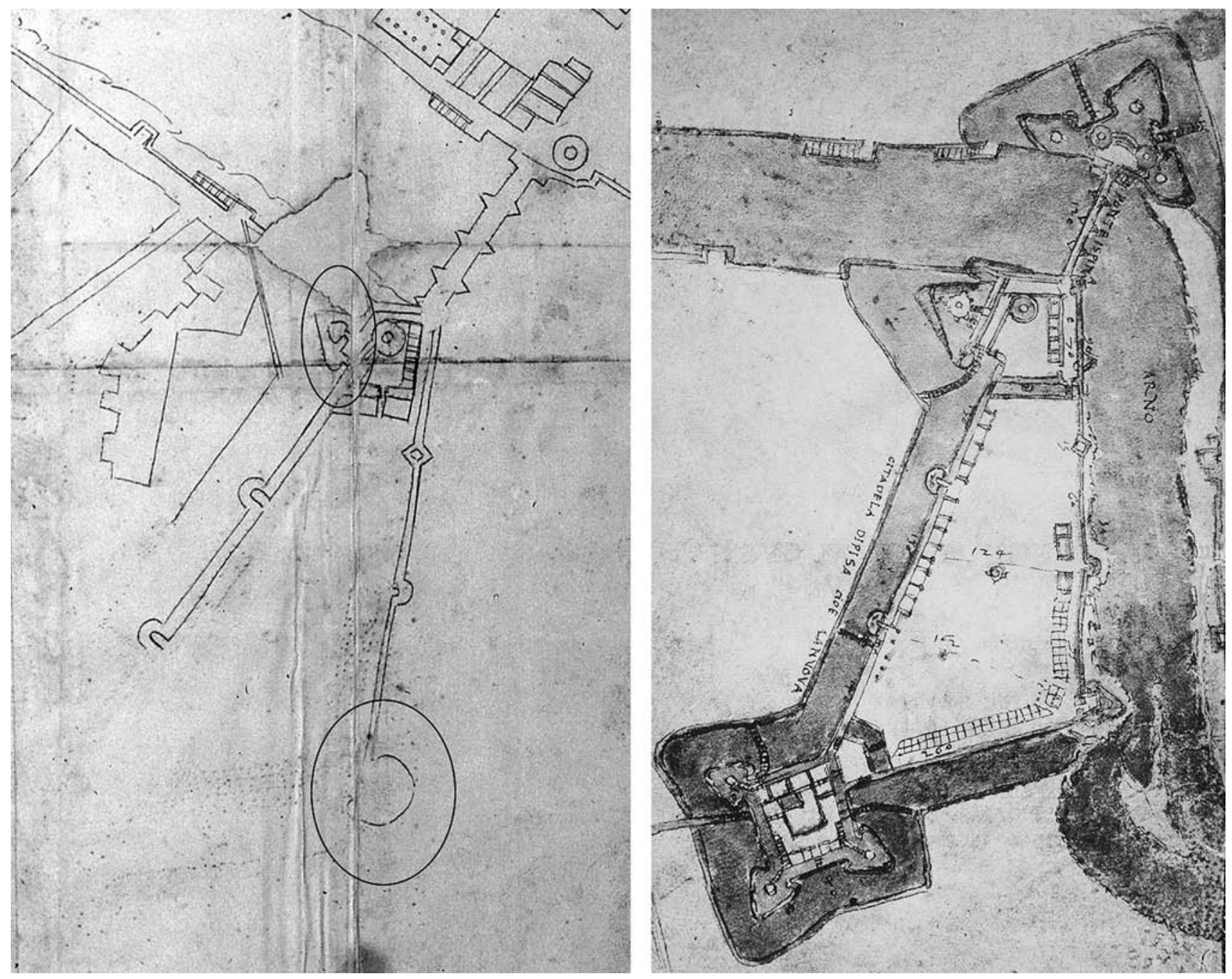

Figure 2 Giuliano da Sangallo, new fortress of Pisa. Left: "Pisa Unfinished," detail; the circles mark the two bastions to which the text refers (Gabinetto Disegni e Stampe, 7950 A, Uffizi, Florence). Right: Taccuino senese, S.IV.8, fol. 3v (Biblioteca degli Intronati, Siena; @ Autorizzazione Biblioteca Comunale Intronati, Siena, 10.02.2015).

and the drawing was passed down to his heirs, who appear to have been familiar with it. An actual tracing can be found in the model book by Giorgio Vasari the younger, which includes an exemplum taken directly from the drawing labeled Tempio di San Sepolcro in Pisa de ss. ${ }^{r i}$ Cav. ${ }^{r i}$ di Malta. ${ }^{17}$ Subsequently the drawing passed from collector to collector until the last, Heinrich von Geymüller, whose entire collection was acquired by the Gabinetto Disegni e Stampe of the Uffizi Gallery. ${ }^{18}$

The problem of authorship would have remained at the level of these indirect hints if an elaborated architectural composition inside the drawing had not provided us with the definitive answer, standing out as a veritable signature of Giuliano. In the northeast section of the town, close to the urban walls, there was, and still is, an archaeological complex popularly known as the Bagni di Nerone (Baths of Nero). ${ }^{19}$
Among the remains, the most significant complete structure is a domed octagonal hall with four corner apses, incorporated in a quadrangular brick shell, in a pattern typical of pre-Trajanic architecture (Figure 4) ${ }^{20}$ It is difficult to establish what was visible at the beginning of the sixteenth century, since earthquakes in that period might well have altered the state of preservation of the remains. In 1548, when the thermal function of the complex was first recognized, the visible structures were described as "replete with soil and full of remains." ${ }^{21}$ In testimony to the complex's crumbling condition, the drawing represents some irregularly scattered fragments of stones in perspective around the complex (Figure 5). The baths themselves, located at the top of the drawing, are depicted in a very polished, detailed, and articulated way, in exaggerated proportion in relation to the rest of the document. 

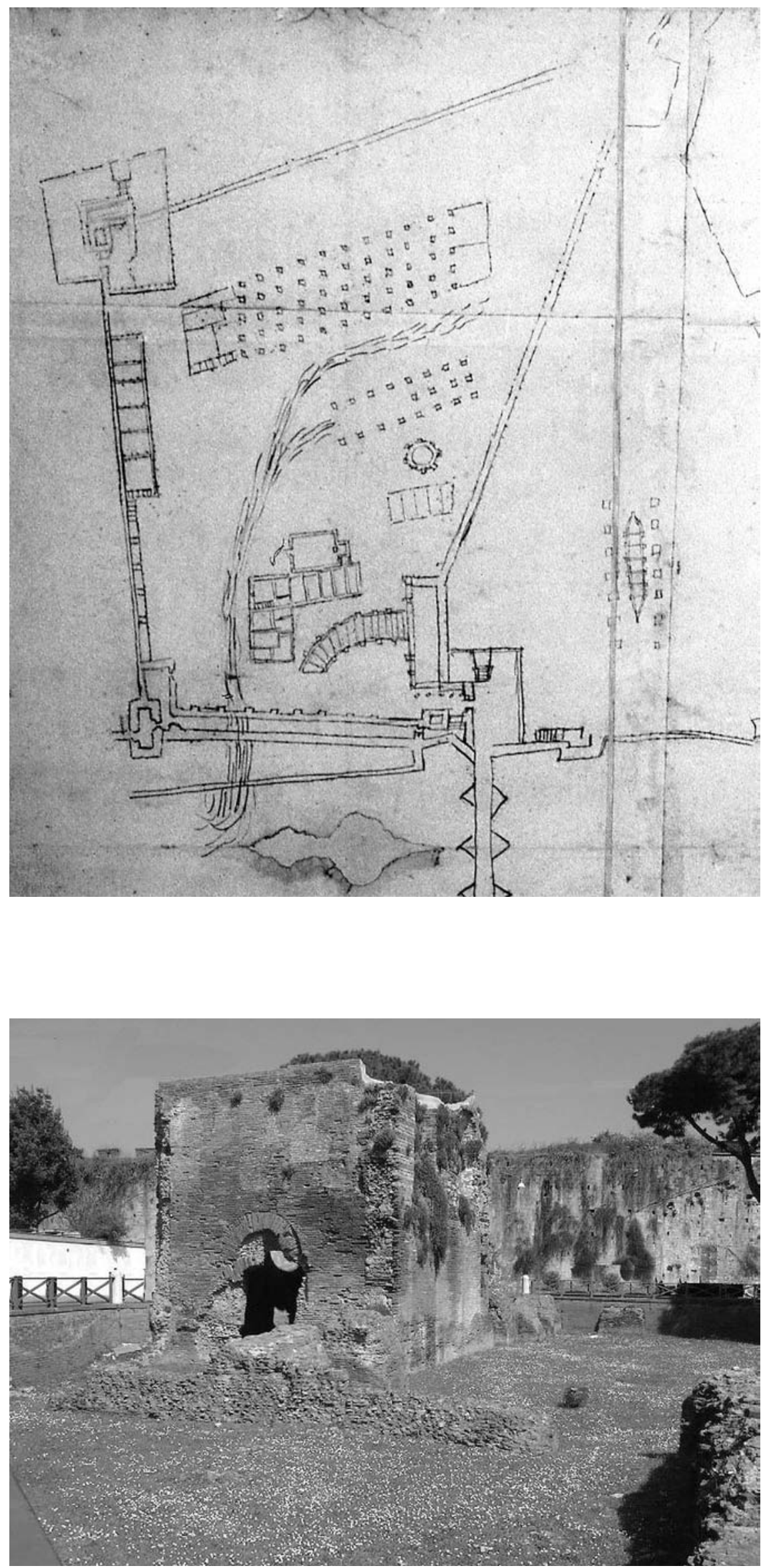

Figure 3 Giuliano da Sangallo, "Pisa Unfinished," detail of the old fortress and the arsenal (Gabinetto Disegni e Stampe, 7950 A, Uffizi, Florence).

Figure 4 The Baths of Nero, Pisa (author's photo, 2013). 


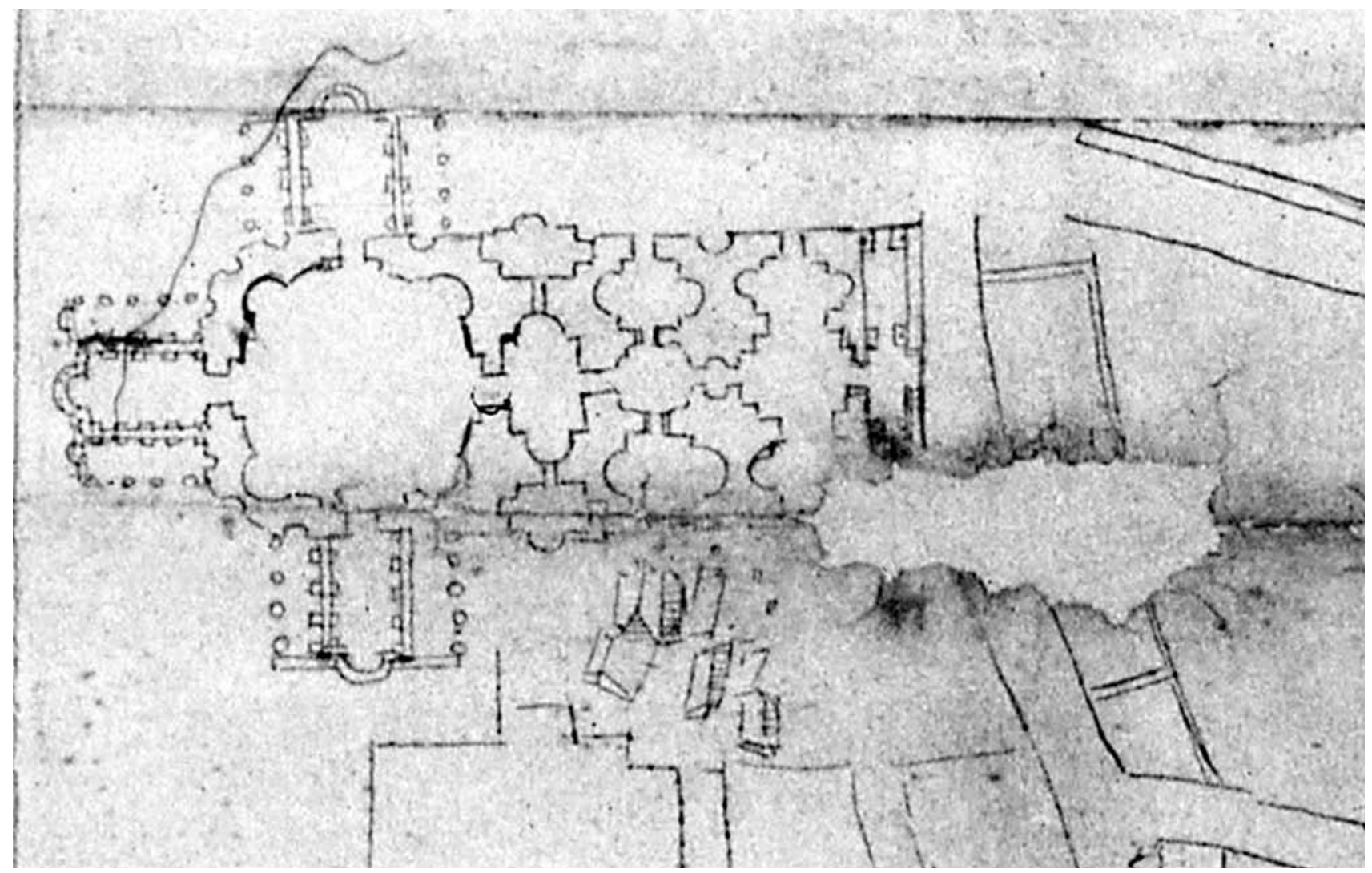

Figure 5 Giuliano da Sangallo, "Pisa Unfinished," detail of the Baths of Nero (Gabinetto Disegni e Stampe, 7950 A, Uffizi, Florence).

The main hall of the Baths of Nero, which is the only element in common with the real structure, is rendered as an octagonal-square-circular form. It is open on four points: three of them lead to apsed galleries, each of which is flanked by a portico on both sides; the fourth passage leads to a small rectangular forceps narthex opening into an octagonal, apsed room, which in turn opens into a rectangular room that finally leads to a corridor. Each of the three rooms opens into other side rooms, which are symmetrically disposed so that all of them are inscribed in a rectangle, as is common in a thermal complex. ${ }^{22}$ Quite surprisingly, however, the overall exterior shape turns out to be close to a basilica with a transept and a long choir, and in fact was perceived as such by Geymüller, a not inexperienced scholar. ${ }^{23}$ Starting as a thermal bath and ending as a church, with no connection to any real architectural typology, this portion of the drawing might be understood as an architectural fantasy.

During the eighteen months Giuliano served as adviser to Bramante on the fabbrica of San Pietro (January 1514-July 1515), he produced three projects for the new basilica. In the first he started developing articulated sacristies on both sides of the choir, as a concatenation of rooms, recalling an already drafted arrangement of a thermal bath. ${ }^{24}$ It is the second one, however, that shows something definitely similar to the drawing under examination here (Figure 6). ${ }^{25}$ It proposes two different versions of the sacristy on the left and right sides of the basilica's axis. The solution for the sacristies of the choir, more contained on the left and fully developed on the right, consists of an octagonal hall where engaged columns round the corners, opening into three columned galleries, two ending with an apse and the third opening into the choir. Borsi has related the layout to the sacristy of San Lorenzo, but there is a closer connection-actually, it is a self-quotation of the central part of the Baths of Nero drafted in the unfinished drawing of Pisa. ${ }^{26}$ The depiction of the thermal complex, identical to the design for San Pietro, thus serves as Giuliano's unequivocal signature.

\section{The Nature of the Drawing and Its Outstanding Features}

The detail of the Uffizi drawing that has just been examined, while offering a definite clue to its authorship, immediately raises a crucial question: How is it possible that a Roman thermal bath in Pisa matches the forms of a new major cathedral of the Christian religion? The answer lies in the nature of the drawing itself, which I will examine by relating it to its 


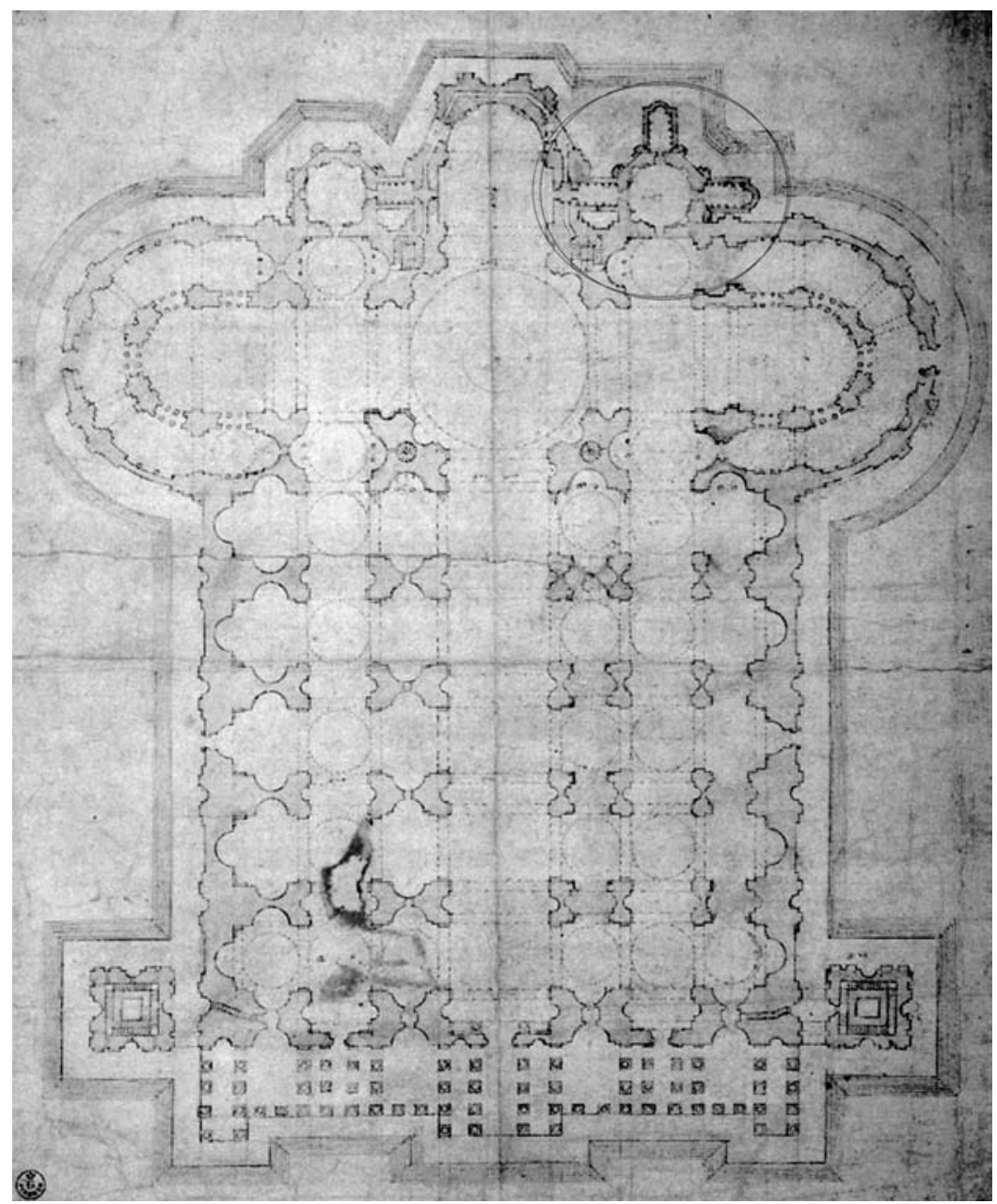

Figure 6 Giuliano da Sangallo, second project for San Pietro; the circle marks the sacristy (Gabinetto Disegni e Stampe, 7Ar, Uffizi, Florence; by permission of the Ministero dei Beni e delle Attività Culturali e del Turismo, Italy; any reproduction prohibited). two reference points: the topography of the city represented and the artist's graphic and built works.

Scholars usually refer to the Uffizi drawing as a pianta because it was one of the first representations of a town delineated with an orthogonal outline, a graphic language used at the time only by the professional class of architects. ${ }^{27}$ Ground plans can be called graphic representations showing the horizontal arrangement of a building or a town drawn to scale, sometimes displayed in numeric or linear form. The Italian language employs the more specific term pianta, which was possibly coined by Raphael within an anthropomorphic concept of architecture: the plan is to a building what the foot's sole (pianta) is to the human body. ${ }^{28}$ Orthogonal outline alone, however, is not enough to achieve a full ground plan, for which exact measurements, drawing to scale, and correct orientation are equally required. After Leon Battista Alberti evoked the idea from antiquity of representing the city as an abstract net of measured points, experimentation in methods and instruments continued, but only in 1513-19, in Raphael's letter to Pope Leo X, was a valid technique for an urban survey formulated..$^{29} \mathrm{~A}$ correct orientation of streets, especially in the early medieval city cores, with their irregularly woven urban fabric, seems to be the weak point of the urban ground plans produced from the end of the fifteenth century through the first half of the sixteenth, such as Leonardo's well-known plan of Imola (1502) or the plan of Ferrara by Pellegrino Prisciani (1494-95), the only two contemporary products available for comparison with the drawing of Pisa. ${ }^{30}$ In both cases, however, those plausible approximations were balanced by the existence of a corroborated process of measuring and preparatory work. The plan of Imola is a high-quality product that only after close analysis turns out to differ from a correct ground plan on many points. The plan of Ferrara, where inside the walls only a few streets are recorded, together with some landmarks, is described by the author as based on previous surveys and drawn to scale. In fact, although it fails to track the course of the streets in relation to the urban walls, the plan is quite accurate, in terms of linear measurements, if compared with modern surveys.

To what extent could the unfinished Pisa drawing be described as the product of a survey and the representation 


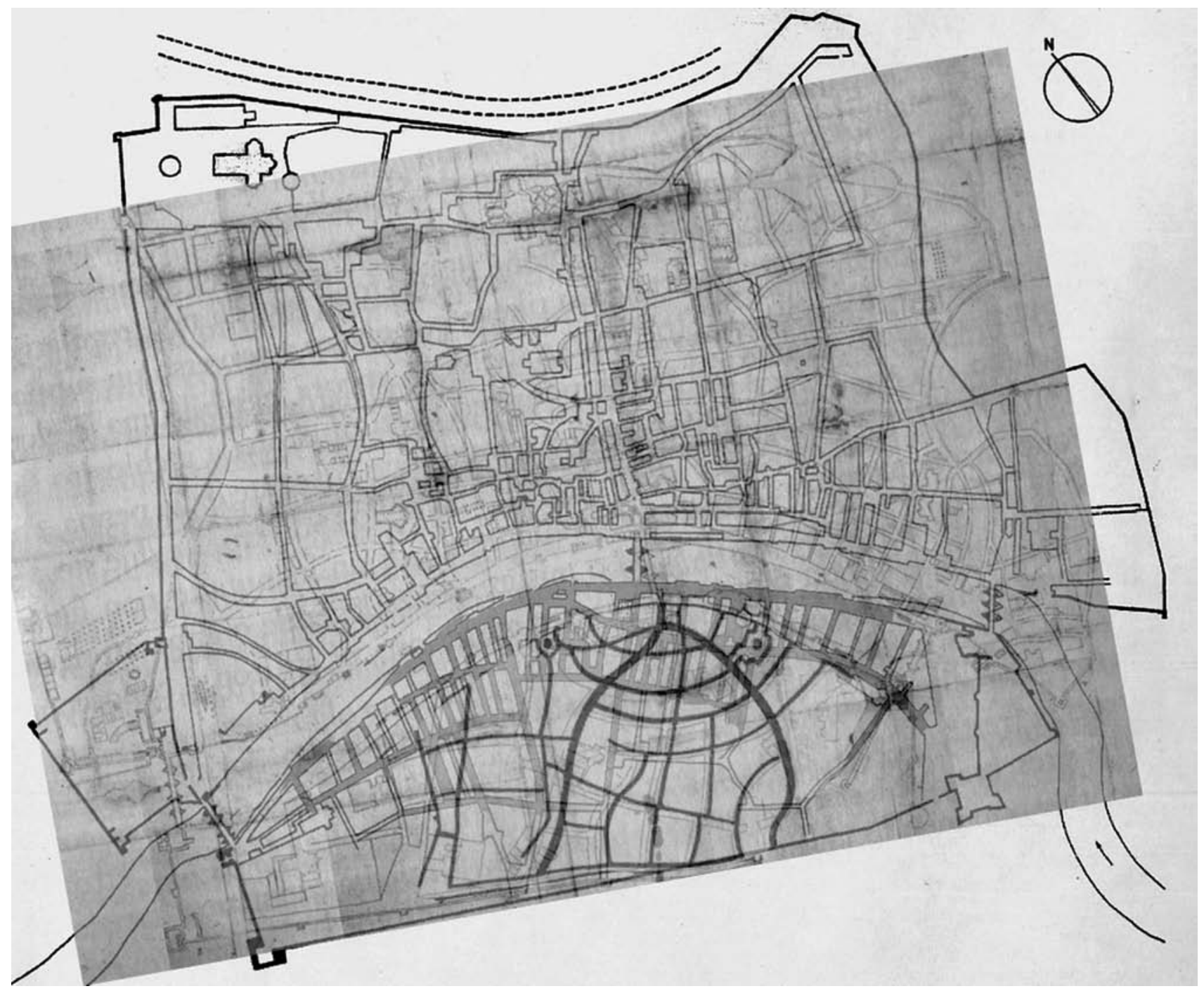

Figure 7 Giuliano da Sangallo, "Pisa Unfinished," superimposed on a basic plan of Pisa, with the layout of the Uffizi drawing in black and the basic plan in gray; in the southern part of the city, the divergences in the paths of the streets are clearly visible (author's elaboration of basic plan).

of a town's topography as its main concern? It is really unlikely that the magnetic compass was used to measure the orientation of the streets. ${ }^{31}$ Significant divergences in the paths of the streets, both in direction and dimension, can be found, especially in the southern part, where they bend in concave lines centered on the main bridge, exactly the opposite of the real situation, and the orientation of the main road, coming from Florence and passing by the fortress, is completely inaccurate (Figure 7). A small, round-edged cross at the meeting point of two major streets, something that has totally escaped scholars' attention, might be interpreted as a basic wind rose, a mark used often in central-point method surveys (Figure 8). Unfortunately, however, the cross shows no relation to the cardinal points, so the meaning remains obscure to everyone but the author himself. ${ }^{32}$

The perimeter of the urban walls is the first, sometimes the only, element for which surveys provide correct orientation and measurements, qualities lacking in the Uffizi drawing. ${ }^{33}$ When compared with the real urban layout, its distortions are so significant that there is no need of verification through measurement: the whole urban form has been stretched out toward the west, with the consequence that the northeastern quarter is compacted while the northwestern one is extended, and an unexplainable protrusion appears in the upper part. The rendering of the internal features is uneven in quality: some areas appear to be carefully recorded, whereas others are fanciful misrepresentations. It seems that partial, limited sketches, like the two held in the Taccuino, were sewn together into a whole map, and the blanks filled in with the results of freehand observation in the field or even imaginative construction. The blocks are simplified and barely outlined, devoid of any internal structure, with a few exceptions where rows of parcels are marked along the street front or churches are positioned, recognizable by the squat 


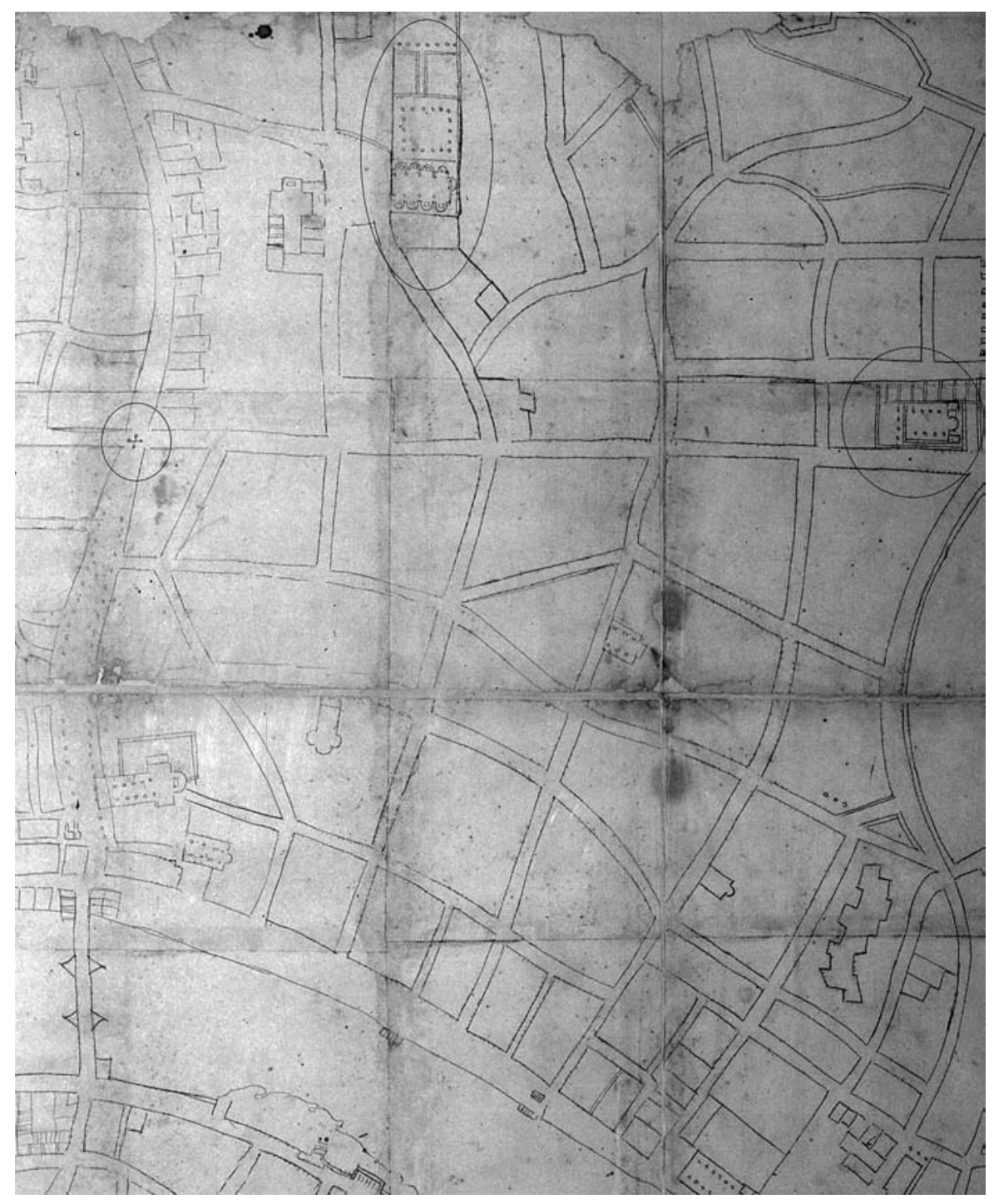

Figure 8 Giuliano da Sangallo, "Pisa Unfinished," detail of the urban area with the small cross circled on the left, the Church of San Francesco circled at bottom right, and the Church of Santa Caterina circled at top center (Gabinetto Disegni e Stampe, 7950 A, Uffizi, Florence). transept or the apsed shape, although the apses have often been added arbitrarily. Churches could have worked as reference points if they constituted a consistent urban net, but many, although important and undoubtedly standing at the time, are omitted, while others are reversed right/left in relation to the streets and are variable in scale. ${ }^{34}$

The inaccuracy, mistakes, and deficiencies of the whole go far beyond the proportion allowed in consideration of the rudimentary instruments and techniques available at the time. The problems are so extensive that it would be very difficult to include this incomplete and imprecise outline of the city in the discourse on the development of urban mapping that occurred in the period. All things considered, it does not seem that pianta is the proper term to define the drawing, or that a proper town survey was the final aim of the draftsman. In the drawing, the objectivity of measured spatial relationships gives way to a great deal of subjectivity. The outline of the city appears to be used as a background or a set for fixing miscellaneous notes, which, in contrast with the roughness of the overall map, are depicted meticulously, sometimes completing feeble charcoal tracks and sometimes apparently from scratch. Special attention is paid to architectural details, like the stairs going up to a tower or down to the river, the number of the piers of the bridges, the altars of some churches, and most of all the piers and the columns, whatever their function and location. The colonnades and loggias, the porches of the clusters, the naves of the churches, the engaged columns in a circular building, the hangars of the arsenal, where a galley is hoisted, may be waiting for restoration. ${ }^{35}$

The internal layouts of a number of churches are also minutely described. Did the author want to represent the glories of the medieval urban past with accuracy? Again, their rendering gives us a contrary answer. The two big churches of the Mendicant orders, San Francesco and Santa Caterina, whose interiors consist of single, large naves, are depicted as divided in three naves ending in apses, possibly to fit the 


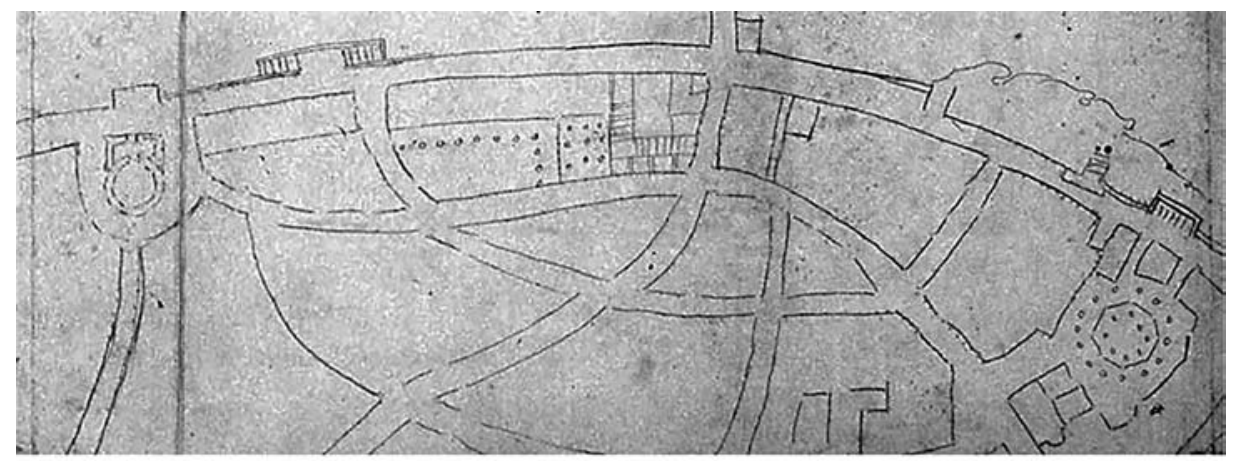

Figure 9 Detail of the Pisa urban area with the Churches of Santa Cristina (left) and San Sepolcro (right). Top: Giuliano da Sangallo, "Pisa Unfinished," detail (Gabinetto Disegni e Stampe, 7950 A, Uffizi, Florence). Bottom: C. Rancini and G. van Lint, "Pianta della città di Pisa," detail, 1846 (private collection).

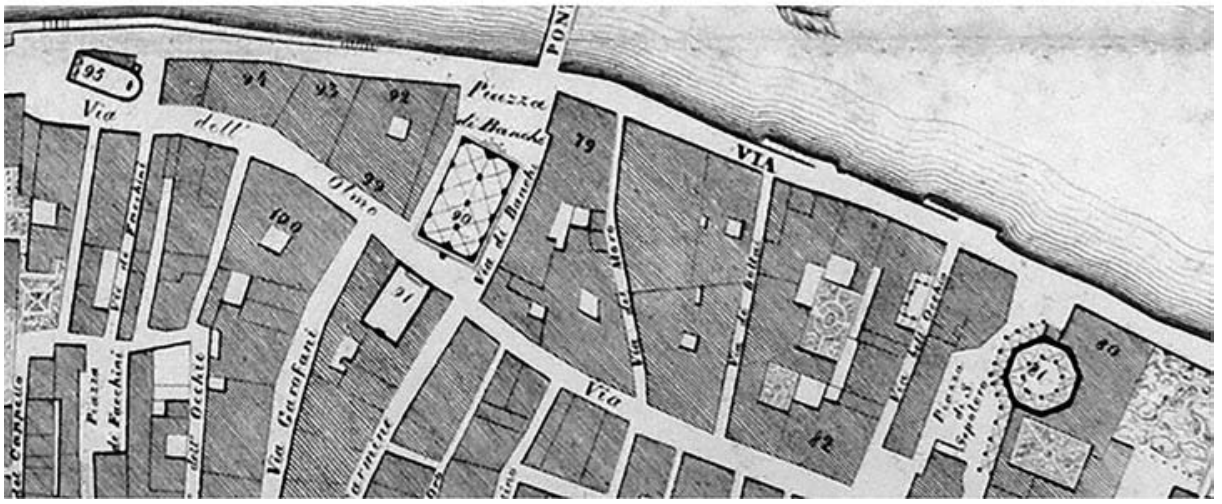

artist's concept of a church (see Figure 8). San Francesco is arbitrarily given a front porch, and the bell tower, located in the back on one side, is symmetrically doubled on the other. In Santa Caterina, the protrusion of a small chapel divided by piers, created on the right of the altar by 1336 , is expanded in the drawing into a border of four apsed chapels on both sides. ${ }^{36}$ It is not clear if their semicircular walls were supposed to be expressed as convex curves on the outside, thus making the church almost a small-scale quotation of Brunelleschi's unrealized project for Santo Spirito in Florence, which Giuliano recorded twice in his sketchbooks. ${ }^{37}$

In the southern part of the city, the very ancient Church of Santa Cristina, a small rectangular apsed volume, is positioned obliquely in relation to the river's present embankment. In the drawing it is turned to face the river directly, isolated from its context, and rendered as a rotunda attached to a rectangular vestibule, with a loose resemblance to an ancient centralized temple, one of Giuliano's favorite themes (Figure 9). To accommodate the edifice properly, the configuration of the surrounding area has been changed to a wider space that is regular and semicircular. Near Santa Cristina, on the same bank of the river, stands a quite remarkable ancient church, San Sepolcro, once belonging to the Knights of the Order of Saint John of Jerusalem. The edifice, consisting of a central higher octagonal body and a lower ambulatory, at the time had a portico (later demolished) on four of the eight sides; the remaining four were closed by adjacent buildings, including the contemporary bell tower, as is clearly shown in a local technician's drawing dating to $1595 .{ }^{38}$ In the Uffizi drawing the octagonal shape, doubled by the internal columns supporting the octagonal drum, is enhanced by being isolated at the center of a regularized square and completely surrounded by a wide portico (see Figure 9).

In addition to the Baths of Nero, this is the second elaborated composition centered on an octagon, a form that was prominent in Giuliano's architecture. The presence of these compositions shifts the attention from the topography of the city, which has proven irrelevant as a reference point, to the artist's graphic and building activity. The octagonal compositions attest to the importance of the Uffizi drawing as a set of Giuliano's experimentations and, at the same time, add an essential clue to the story of his lifelong speculation on this form.

The net polygonal definition of the San Sepolcro complex is undoubtedly closer than the Baths of Nero to what can be considered the starting point for Giuliano's speculation on the octagon. When he was beginning his career in architecture, the octagonal Baptistery of Florence was possibly the first monument to impress the mind of the young woodworker. At the time, it was regarded as a true monument of antiquity. The legend that described it as a temple of Mars that had been converted into a Christian church passed through the late Middle Ages and reached the quattrocento architects who were searching for a new language..$^{39} \mathrm{It}$ is tempting to suggest that Giuliano absorbed the Baptistery's centralized geometry and harmonically expanded space as 


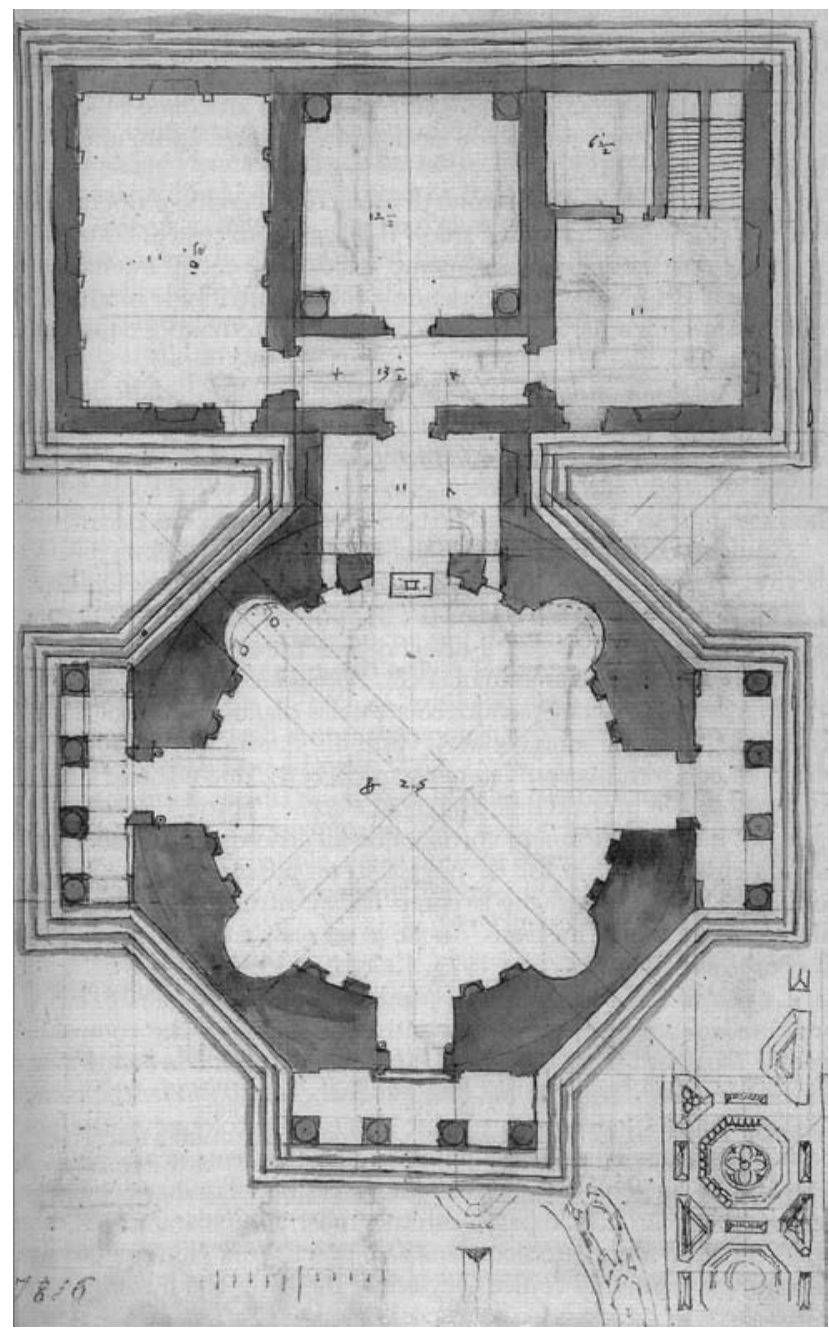

Figure 10 Giuliano da Sangallo, project for a church (Gabinetto Disegni e Stampe, 7816 A, Uffizi, Florence; by permission of the Ministero dei Beni e delle Attività Culturali e del Turismo, Italy; any reproduction prohibited).

the ideal core of any architectural composition. It is no wonder that the Baptistery later appeared in one of his sketchbooks accurately described among a few medieval buildings. ${ }^{40}$ Giuliano reproduced its form again in 1489, when he was involved in building the wooden model for the sacristy of Santo Spirito, the design for which Lorenzo the Magnificent himself was responsible. A document refers to the model as "an octagon with the tribune shaped like sangiovanni" (i.e., the Baptistery). ${ }^{41}$ The wooden model is now lost, but the form of the built sacristy did not turn out as a simple octagon like the Baptistery, because four apses expand the oblique sides. This is most likely due to Giuliano's personal experience of Roman architecture during his journeys to central and southern Italy in the period 1483-88. The Florentine and Roman components of the sacristy have been widely commented on by scholars who have alternatively stressed either the Roman or the Florentine. ${ }^{42}$
An interaction between Florentine and Roman components seems to underlie Giuliano's experimentation with the octagonal form and its dynamic, metamorphic relationship with the circle, which is witnessed in a considerable number of the artist's sketches, disseminated throughout his career and sometimes even reelaborated in different periods. The graphic geometrical genesis of this form, resulting from the combination of square, circle, and octagon, is illustrated quite clearly in another Uffizi drawing in the same Geymüller collection; the drawing, which represents a project for a church, has been convincingly attributed to Giuliano (Figure 10). ${ }^{43}$ The basis for the whole is a square, which is not supposed to be visible in the building, because the four diagonals push the corners into apsed expansions. Two circles are drafted from the center of the square: the internal one defines the hall opened by four entrances, thus dividing the wall in eight segments articulated by engaged columns; the exterior one fixes the points of tangency of the octagonal wall outside.

This peculiar form, the result of a speculation on the octagon, is also clearly recognizable as a distinguishing mark in Giuliano's freehand sketches, such those of the Baths of Nero or the antique monuments that constitute the bulk of his two sketchbooks. Among his many sketches, three are particularly significant for approaching this issue: those of the Baths of Viterbo, the so-called Studio of Varro, and the so-called Temple of Cumaean Sybil (a name borrowed from Virgilian poetry), also known as the Temple of Apollo. ${ }^{44}$ These edifices belong to different periods of the Roman Republic and the Roman Empire. They are all connected with thermal complexes, and this is not by chance. Among the various rooms that constituted a bath, three were particularly interesting: the tepidarium (the warm bath), the calidarium (the hot bath), and the laconicum or sudatorium (the sweating room), the structure of which was determined by function. Needing to be covered by barrel vaults or cupolas in order to maintain the temperature produced by central heating, these rooms were often built in the form of rotundas, or centralized spaces, and were, therefore, highly appealing to a Renaissance architect.

Giuliano's sketches of these interiors are not the results of an archaeologist's approach. On the contrary, they show a high degree of subjectivity that is fully noticeable if compared, on one hand, with the evidence provided by the present remains and archaeological excavations and, on the other, with the records of other artists who traveled along the same routes, in search of the same encounters with classical antiquity. In rendering the three edifices, Giuliano always enhanced the major hall, an octagon expanded with apses, each time outlining its combination with the circle. More specifically, in the Baths of Viterbo he used the 


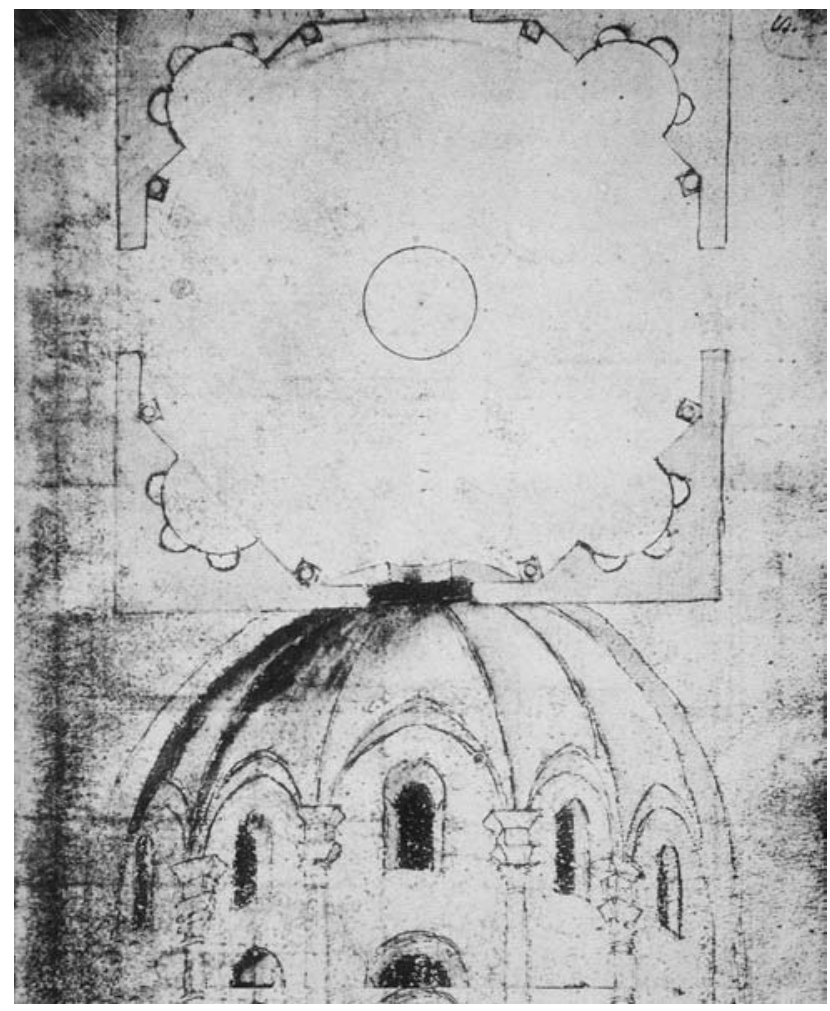

Figure 11 Giuliano da Sangallo, Baths of Viterbo (Taccuino senese, S.IV.8, fol. 8r, Biblioteca degli Intronati, Siena; @ Autorizzazione Biblioteca Comunale Intronati, Siena, 10.02.2015).

engaged columns at the corners to create a rounded surface of the walls, a feature that he replicated more than once in subsequent drawings (Figure 11). ${ }^{45}$ The sketches include personal additions. In the sketch of Varro's studio, Giuliano added a fourth apse, not present in the original building where a pier was built for sustaining the vault, for the sake of symmetry (Figure 12). ${ }^{46}$ In the Temple of the Sybil, he arbitrarily appended two rectangular bodies to opposite sides while he tightly closed the internal circular shell with an external octagonal, both prominent in their thick outline (Figure 13). ${ }^{47}$

Other artists who considered the same buildings did not grant the octagon the same attention; rather, they made it equivalent to other forms as part of larger complexes. ${ }^{48}$ In particular, Francesco di Giorgio recorded the Temple of the Sybil as the nucleus for a cluster of adjacent circular and rectangular rooms of different sizes (Figure 14). In sketching Varro's studio he depicted very clearly the lines of the octagon, thus virtually discounting its apsed expansions. The form is still visible, but it is immersed in a concatenation of rooms, probably according to his needs. He interpreted the remains as houses and the centralized space as the atrium, the arrangement of which he tried to reproduce in his designs for villas (see Figure 14). ${ }^{49}$

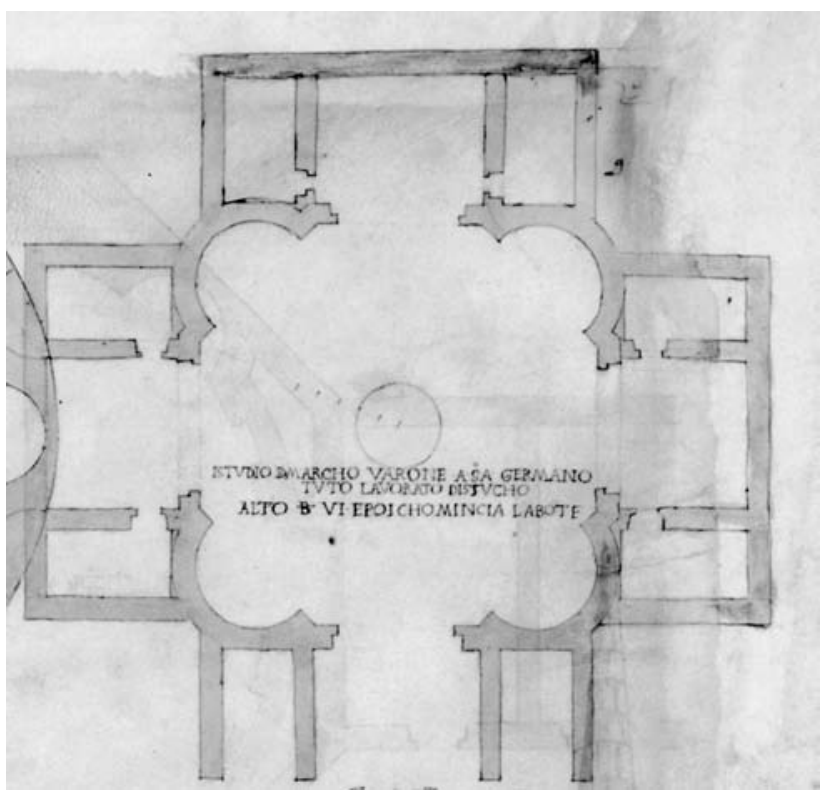

Figure 12 Giuliano da Sangallo, Studio of Varro (Codex Barberinianus Latinus 4424, fol. 8r, Biblioteca Apostolica Vaticana, Rome; @ 2015 Biblioteca Apostolica Vaticana).

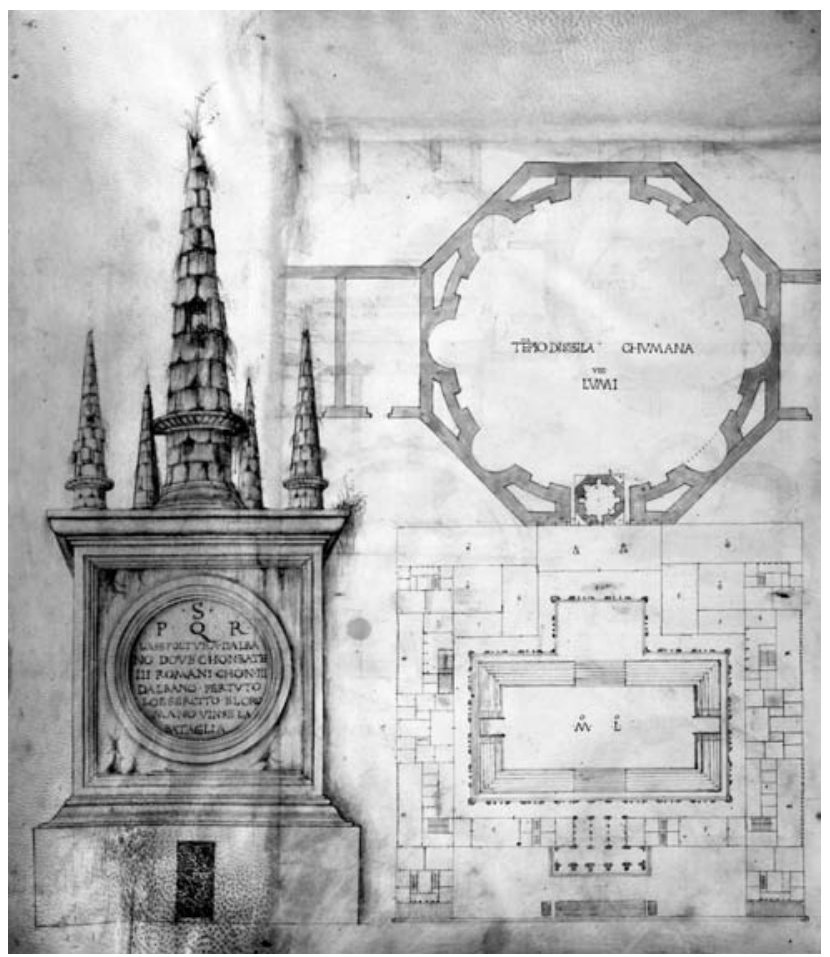

Figure 13 Giuliano da Sangallo, Temple of the Cumaean Sybil (top) and the original project for the palace of the king of Naples (bottom) (Codex Barberinianus Latinus 4424, fol. 8v, Biblioteca Apostolica Vaticana, Rome; @ 2015 Biblioteca Apostolica Vaticana).

Evidently, neither Francesco di Giorgio nor the majority of Renaissance artists operated as archaeologists. In their collective pursuit of the investigation of antiquity, conscious 

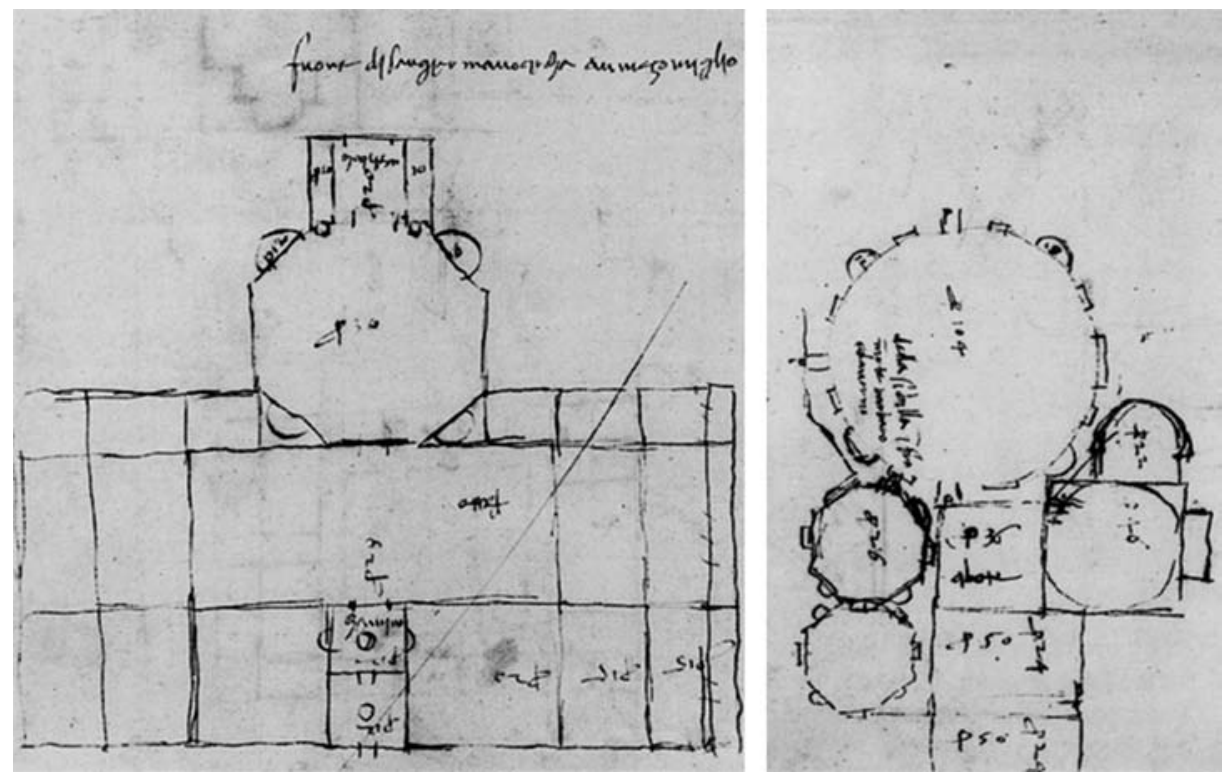

Figure 14 Francesco di Giorgio, Varro's villa (left) and the Temple of the Sybil (right) (Gabinetto Disegni e Stampe, $322 \mathrm{Ar}$ and $329 \mathrm{Ar}$, Uffizi, Florence; by permission of the Ministero dei Beni e delle Attività Culturali e del Turismo, Italy; any reproduction prohibited).

alteration of the real forms was viewed as the legitimate domain of the artist's invention; this affected not only direct records but also artists' copies of others' drawings. ${ }^{50}$ This issue has been deeply investigated in regard to Giuliano's copies of Ciriaco d'Ancona's drawings of Greek buildings that Giuliano never saw. ${ }^{51}$ The transformations, in some cases radical, were recognized to have been determined both by the influence of Roman architecture that Giuliano knew personally and by a notion of good architecture into which the remains should fit. Axial symmetry, the importance of which Vitruvius had stressed, was one of the most authoritative principles that drove the artists' hands in their reconstructions. Even in his ground plan of Rome, Leonardo Bufalini imposed symmetry by completing the plans of fragmentary structures that were visible at the time..$^{52}$

It should be stressed that in addition to influential notions and aesthetic guidelines that were shared among the artists, another principle underlay the treatment of ancient remains: the intended use of the drawings substantially determined their rendering and differentiated each artist's work. Francesco di Giorgio finished his rough sketches to make them function as illustrations for his treatise. ${ }^{53}$ Giuliano did not compose a treatise, but his sketchbooks can be regarded as biographical collections; set up and revised constantly throughout his life, they are witnesses to a personal architectural experience, a display of forms from which he drew inspiration as well as forms that he created from scratch. ${ }^{54}$ There is no real difference between the two types of forms.

The manner in which Giuliano recorded the expanded octagonal forms of antiquity matches so perfectly with his actual designs that in many cases the first can be read as revealing anticipations of the latter..$^{55} \mathrm{In}$ fact, it is not correct to describe them in terms of prototypes and derivations, even chronologically speaking. Both would be better understood as depending on the same spatial idea to which he was attracted, in which the octagon was a dynamic form, in constant dialogue with the circle, always struggling between expansion and limitation. The connection between the two spheres of activity, recording and designing, is so close that it produced a quite interesting misunderstanding: the incautious copyist of the Codex Escurialensis, dealing with the sheet of the Codex Barberinianus where the Temple of the Sybil partially overlaps a design for a palace, incorporated in his copy of the ancient temple the expanded octagon that actually belonged to the palace (see Figure 13). ${ }^{56}$

Giuliano was attracted by the great spatial potential of this form in interior architecture and exploited its effects in designs of civil and religious character, both as a self-sufficient and closed space and as a milieu for radiating space in adjacent chambers. In his projects for the palace of King Ferdinand I of Naples, he experimented with the organic inclusion of the octagonal form in a complex composition, where it was destined for the chapel, differently disposed in two alternative solutions (Figure 15).$^{57}$ In both solutions, the expanded octagon plays a role that differentiates it from the rest of the building. It is a religious and self-sufficient space, working as a point of arrival, not of transition.

This last relational function is played out in another project for a palace that appears in very similar versions in both sketchbooks, the Codex Barberinianus and the Taccuino (see Figure 15). ${ }^{58}$ Indeed, one of Giuliano's last designs, dated to the Roman years of his cooperation with Bramante, 
Figure 15 Giuliano da Sangallo, late project for the palace of the king of Naples (left) and project for a palace (right) (Codex

Barberinianus Latinus 4424, fol. 39v and fol. 9r, Biblioteca Apostolica Vaticana, Rome; (C) 2015 Biblioteca Apostolica Vaticana).
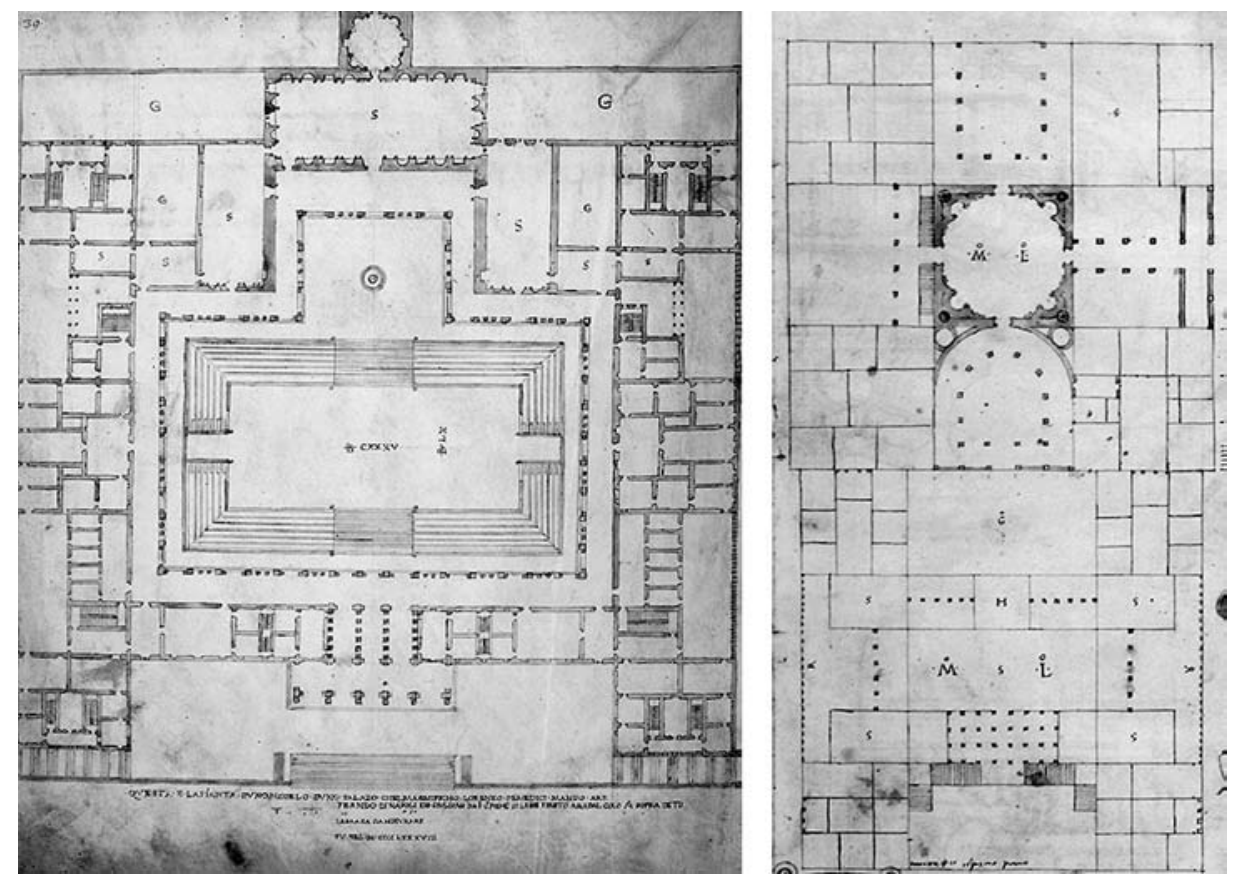

a complex, sophisticated, and possibly redundant composition, brings the attention back to religious architecture (Figure 16). ${ }^{59}$ An octagonal exterior shell includes a round internal space with alternating rectangular and semicircular niches, which becomes the melting pot of disparate suggestions: from Bramante's contemporary motives, from antiquity (the Temple of the Sybil), from early Christian monuments like the Santa Costanza mausoleum in Rome, and from the Florence Baptistery, the starting point of the artist's life and activity. For Giuliano, experimenting with the circle and the octagon appears to have been a constant exercise, not restricted to the sphere of drawing. The arrangement of the sacristy at Santo Spirito has already been commented on, and its close relation to the Baths of Viterbo and the Studio of Varro acknowledged. The octagonal hall was annexed to the existing church as a later appendix, working as a self-sufficient room.

Under the new fortress in Pisa, Giuliano shaped one of the underground chambers of the bastions as a rotunda covered with a cupola and another as an octagon expanded to four apses in the oblique sides and connected with minor similar rooms (Figure 17). After the fortress lost its military role, the structures were neglected, and flooding caused by the closeness of the river hid the chambers from scholars' attention and direct inspection. A superficial hint of these structures can be found only in Marchini's biography of Giuliano, where there is a mention of his attempt to reproduce in the underground chambers "particular forms of antique edifices." ${ }^{\circ 0}$ The entrance area to this complex was covered by a barrel vault, modeled by octagonal lacunars, two

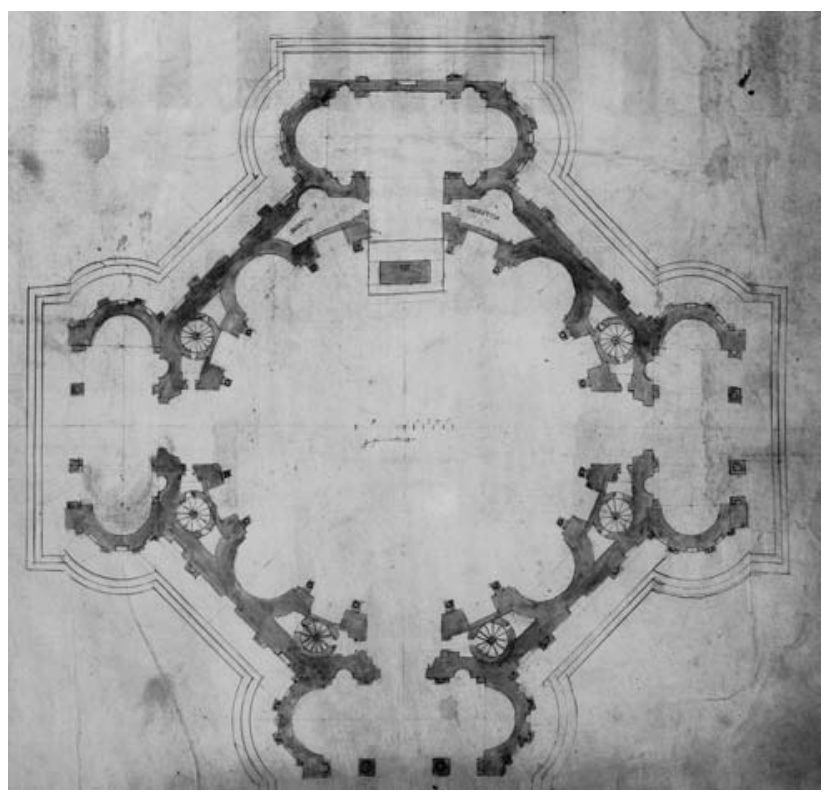

Figure 16 Giuliano da Sangallo, project for a church (Codex Barberinianus Latinus 4424, fol. 61r, Biblioteca Apostolica Vaticana, Rome; (c 2015 Biblioteca Apostolica Vaticana).

of which, working as an oculus, allow natural light into the interior (Figure 18). Other octagons open the tops of the domes in the surrounding rooms (Figure 19). From a passage in the internal hall a few steps descend to a lower level. A tunnel leads to the octagonal chamber, a chapel possibly, where marks of many different water levels are clearly visible. All the sides expand to niches framed by brick arches, above 


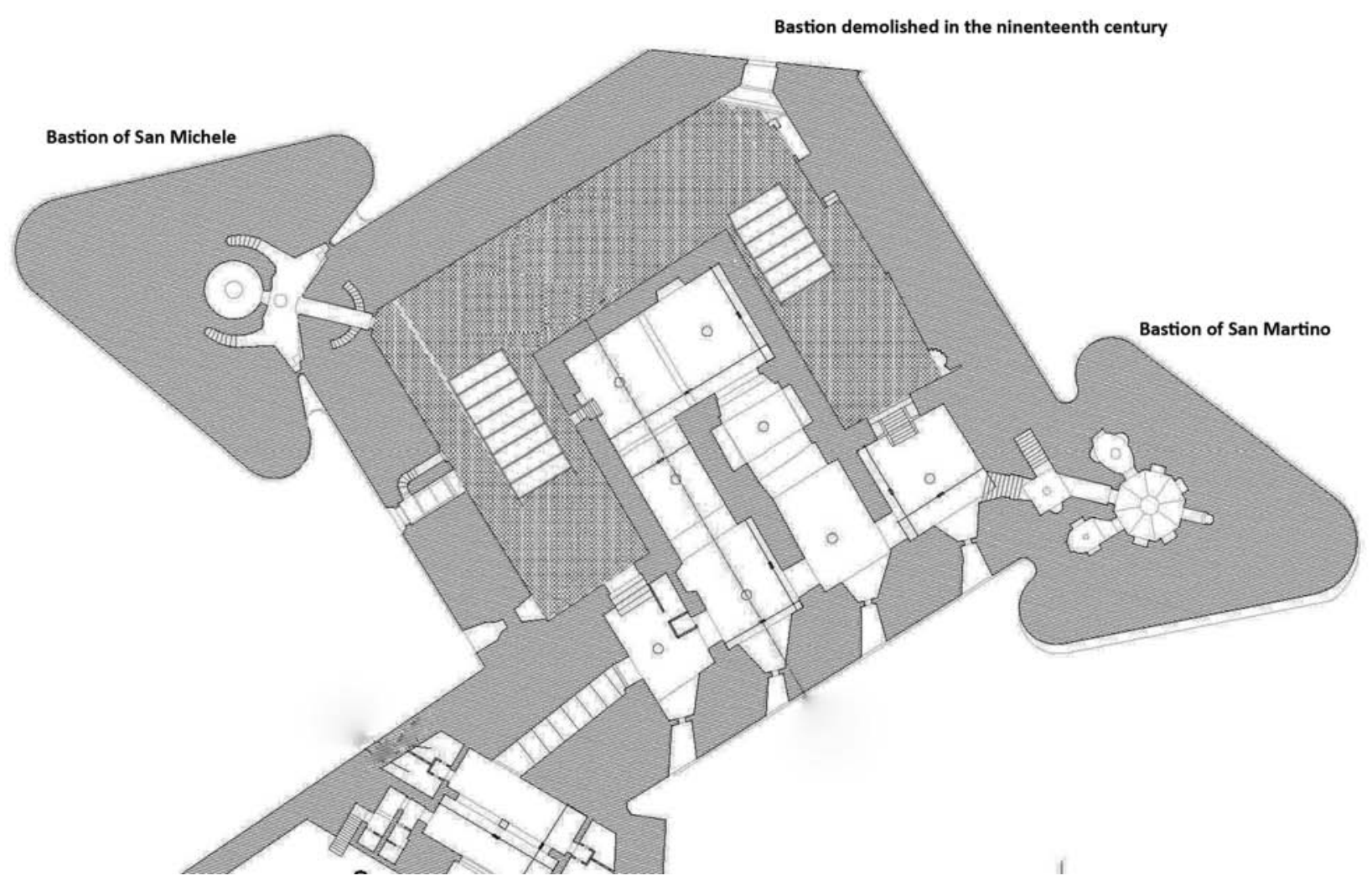

Figure 17 Survey of the new fortress, Pisa (author's elaboration).

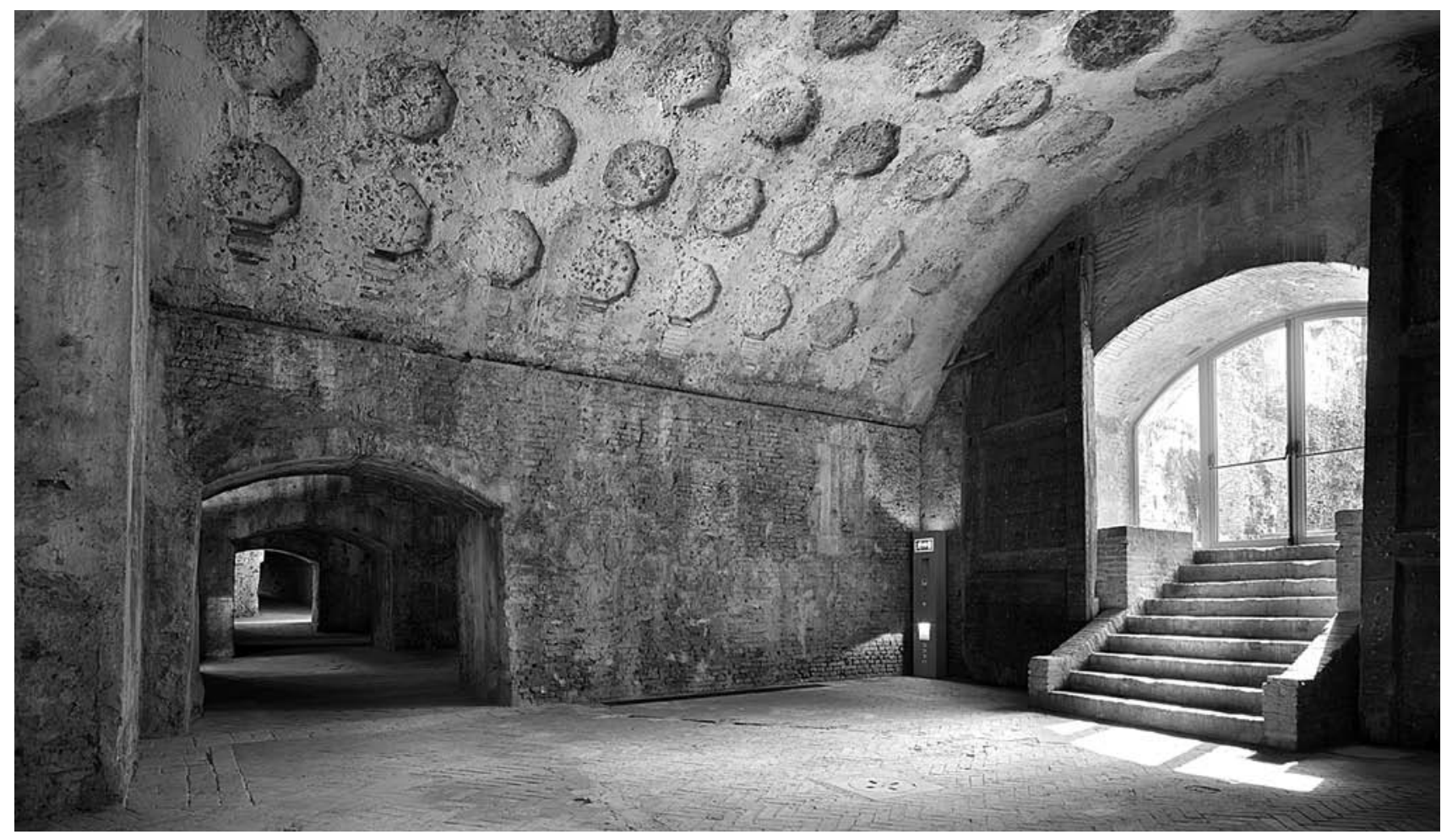

Figure 18 Entrance hall to the underground chambers of the bastion of San Martino, Pisa (photo by Mario Ciampi, with permission of the Comune di Pisa). 


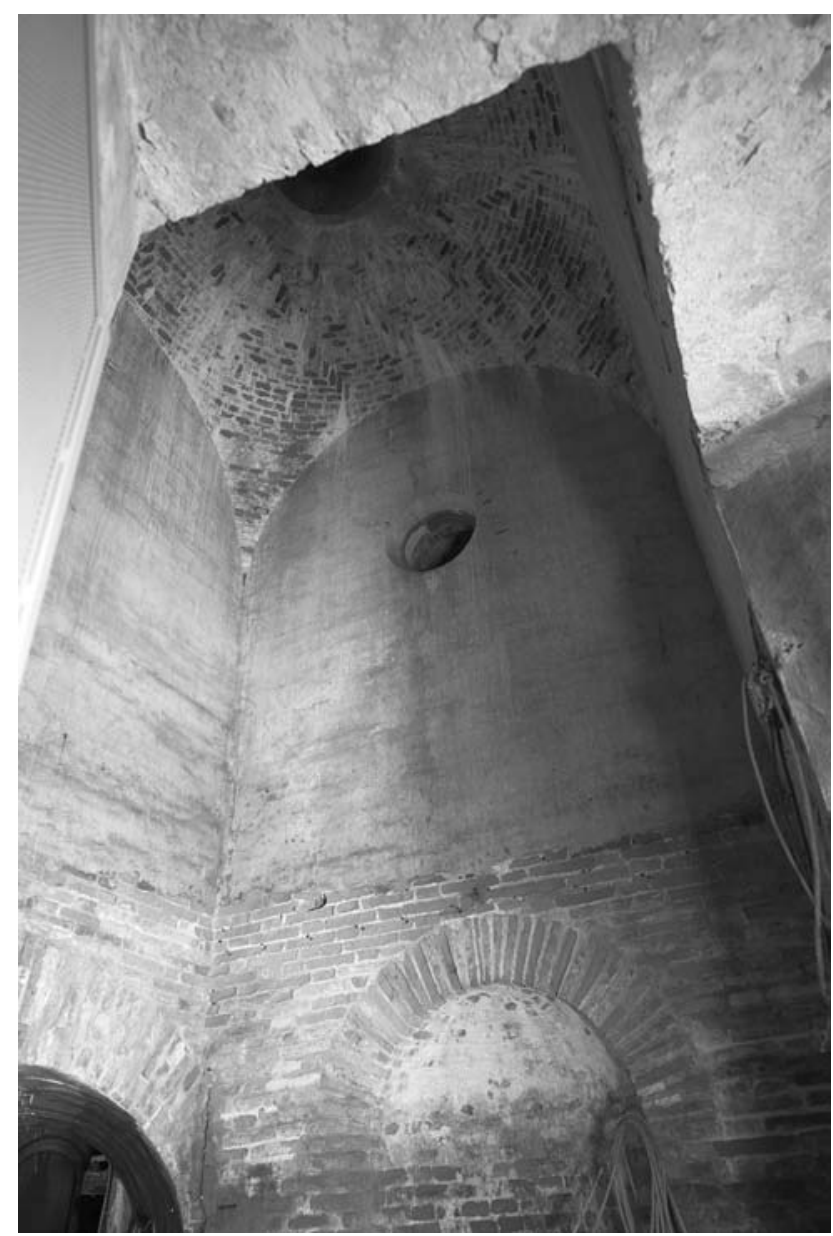

Figure 19 Small cupola with octagonal oculus in the underground chambers of the bastion of San Martino, Pisa (photo by Laboratorio Fotografico del Dipartimento di Civiltà e Forme del Sapere, Università di Pisa, 2014).

which the polygon, outlined by a molding, gives way to the expansion of the dome, reaffirming itself at the top through an octagonal oculus (Figure 20).

\section{Conclusion}

To come back to my initial question, the apparently inexplicable gap between the thermal complex of Pisa and the basilica of San Pietro can be bridged quite easily if we consider both as episodes belonging to the same domain of drawing. At the end of the fifteenth century architectural drawing was just taking its first steps toward an identity. If the definition of a method was still under construction, the meaning of drawing was, at that moment, far more comprehensive than it would become in the following century. It should be noted that in the Italian language, where that culture originated, the word disegno means at the same time the mental process of creation and its material expression, the drawing. Despite our inclination to distinguish typologies of drawings and

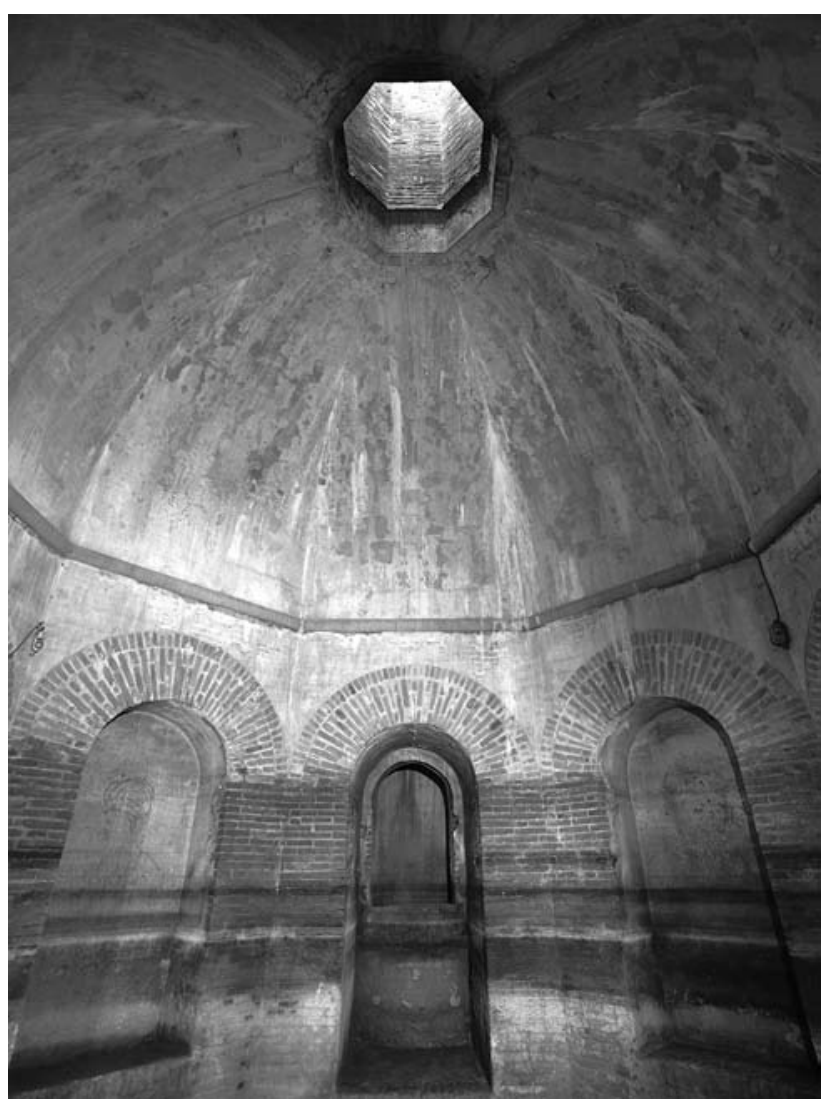

Figure 20 Octagonal chamber of the bastion of San Martino, Pisa (photo by Mario Ciampi, with permission of the Comune di Pisa).

codify methods through specific rules, no such categorization seemed to be present at the time among the architects, for whom the borders between surveying, interpreting, and designing were blurred. Drawing was considered in its full potential as a medium for architectural communication in the widest sense.

Drawing started being used as an intermediary between architects and the people who commissioned their works. During his stay in Pisa, to submit problems and solutions and obtain the approval of the Florentine government, Giuliano traveled to and from Florence carrying disegni, which had been used in Florence for defense decisions from at least $1460 .{ }^{61}$ None of these disegni has survived. We can assume that they were rough working instruments focused on narrow areas where prominent objects were often pointed out by crosses. ${ }^{62}$ The public authority did not consider them worthy of becoming part of the legal record, as were written documents. More significantly for the architect himself, each drawing was a step in his professional growth, mirroring a personal approach to design. On the same sheet, curiosities, reconstructions of the past, notes for edifices to be built, and faithful records could find places next to each other. ${ }^{63}$ In the Uffizi drawing, possibly for the only time, 
this process happened at an urban scale. Giuliano is undoubtedly one of the first artists to accept Alberti's demand for a graphic representation of a whole city. His unfinished Pisa drawing attests to the interpretation that he regarded the city as a spatial, architectural object and, accordingly, depicted it with an orthogonal outline, but the connection ends there. This unique sketch sheet, far from being the visual record of a measured urban space (a survey), assumes the value of a personal record that belongs to the town no more than to the author's own speculation.

What Giuliano really wanted to do once he had finished his work is a question that cannot be answered conclusively at the moment. Indeed, he recorded an urban spatial matrix, but he used it like a store of his experiences and researches in architecture during his three years' stay in Pisa, using different modes of drawing. We can trace records of surveys and what are almost snapshots of works in progress in some specific areas of the town. Evidence of interpretation and creative design prevails in the renderings of the crumbling remains of antiquity, but even more significantly in the renderings of some important medieval churches and their surroundings, whose structures stood in good condition at the time. The octagonal form, which played an important role as a spur to the process of creation throughout Giuliano's career, also has a significant place in the drawing. In the octagons of the thermal complexes that he recorded in his sketchbooks, Giuliano saw halls of villas, private chapels, sacristies, churches, and fortification rooms. From the debris of the Baths of Nero, he imagined spaces that would be worthy of the new San Pietro, thus creating in his architectural fancies a paper bridge between a city that for some years he had explored and a new Rome that never came into existence.

Lucia Nuti, professor of architectural and urban history, researches urban architecture and urban imagery. Publications include articles in Word and Image, The Art Bulletin, Imago Mundi; books: Ritratti di città. Visione e memoria tra Medioevo e Settecento (1996); Cartografie senza carte. Lo spazio urbano descritto dal Medioevo al Rinascimento (2008); and http://asict.arte.unipi.it.

\section{Notes}

1. Josef Plöder maintains that the first part of the writing is in Giuliano's hand. See Josef Plöder, Bramante e gli altri: Storia di tre codici e un collezionista (Florence: Olschki, 2006), 232-33.

2. The plan has been referenced mainly in relation to Pisa's topography. See Luigi Pedreschi, "Ricerche di Geografia urbana," Rivista geografica italiana 58, no. 2 (1951), 126; Anna Rosa Masetti, Pisa storia urbana (Pisa: Nistri Lischi, 1964), 19, 53; Giancarlo Severini, Architetture militari di Giuliano da Sangallo (Pisa: Lischi, 1970), 57; Antonino Caleca, "A. XIV. a. 1.," in Livorno e Pisa: Due città e un territorio nella politica dei Medici (Pisa: Pacini, 1980), 203; and especially Emilio Tolaini, Forma Pisarum: Problemi e ricerche per una storia urbanistica della città di Pisa (Pisa: Nistri Lischi, 1967), 72-95. For comments on the drawing in relation to survey methods and city plans, see Daniela Stroffolino, La città misurata: Tecniche e strumenti di rilevamento nei trattati a stampa del Cinquecento (Rome: Salerno Editrice, 1999), 132; Hilary Ballon and David Friedman, "Portraying the City in Early Modern Europe: Measurement, Representation, and Planning," in Cartography in the European Renaissance, ed. David Woodward (Chicago: University of Chicago Press, 2007), 683-84; Lucia Nuti, "La pianta di Pisa di Giuliano da Sangallo," in Rappresentare la città: Topografie urbane nell'Italia di antico regime, ed. Marco Folin (Reggio Emilia: Diabasis, 2010), 145-56. For comments on Sangallo's activity, see Heinrich von Geymüller, Les projets primitifs pour la basilique de Saint-Pierre de Rome par Bramante, Raphael Sanzio, Fra Giocondo, les Sangallo, etc. (Paris: J. Baudry, 1875), 285; Cornelius von Fabriczy, Die Handzeichnungen Giuliano da Sangallo kritishes Verzeichnis (Stuttgart: Gerschel, 1902), 116-17; Giuliano Marchini, Giuliano da Sangallo (Florence: Sansoni, 1942), 102; Stefano Borsi, Giuliano da Sangallo: I disegni di architettura e dell'antico (Rome: Officina, 1965), 431; Josef Plöder, Heinrich von und die Architekturzeichnung Werk Wirkung und Nachlaß eines Renaissance forschers (Vienna: Böhlau, 1998), 428; Plöder, Bramante e gli altri, 232-33. No mention at all of the drawing is in the recent monography Sabine Frommel, Giuliano da Sangallo (Florence: Edifir, 2014). 3. Giorgio Vasari dedicated one of his Lives to the Sangallo brothers. See Giorgio Vasari, Le opere, ed. Gaetano Milanesi (Florence: Sansoni, 1906), 4:267-309. The most thorough account of Giuliano's life and career remains Marchini, Giuliano da Sangallo.

4. In the drawing, just below the cathedral square, close to the urban walls in an unbuilt area, a number of large blocks disposed in a very regular layout are defined by a sharp double line that stands out from other lines, the same kind of double line used for defense walls and thick structures. Below this double line and in other parts of the city, especially close to the river, broken lines distinguish some streets. Tolaini speculates that these lines marked urban transformation projects, but no such projects were ever formulated in those areas. Tolaini, Forma Pisarum, 93-94. In the finished drawings in both of Giuliano's sketchbooks, broken lines usually represent architectural structures that are not visible. In this case, however, since broken lines are applied to street fronts, it seems more appropriate to interpret them as provisional lines.

5. Ibid., 94-95.

6. Regarding the practice of reusing previous surveys, see, for instance, the manuscript map of the fortifications of Rome in Codex Barberinianus Latinus (hereafter Cod. Barb.) 4391[B], Biblioteca Apostolica Vaticana, Rome. This map is believed to be related to Leonardo Bufalini's plan. Jessica Maier comments on it in "La pianta di Roma di Leonardo Bufalini," in Folin, Rappresentare la città, 164. On Leonardo's Imola plan, see Fausto Mancini, "Danesio Maineri, ingegnere granducale, e la sua opera alla rocca e alle mura di Imola sul finire della signoria manfrediana (1472-1473)," Studi Romagnoli 26 (1975), 163-210. On the subject of drawings and their copies, see Andreina Griseri, "Il disegno," in Storia dell'arte italiana: Grafica e immagine (Turin: Einaudi, 1980), 195-96; Daniela Lamberini, "Funzioni di disegni e rilievi delle fortificazioni nel Cinquecento," in L'architettura militare veneta del Cinquecento, ed. Sergio Polano (Milan: Electa, 1988), 51, 53. 7. Vasari, Le opere, 4:285.

8. See the documents in Giovanni Gaye, Carteggio inedito d'artisti dei secoli $X I V, X V, X V I$ (Florence: Giuseppe Molini, 1840), 2:109-10. For a full account of the history of the fortress, see La fortezza di Pisa: Dal Brunelleschi al Giardino Scotto-Storia e restauro (Pisa: ETS, 2009).

9. Gaye, Carteggio, 2:112-34.

10. While working in Pisa, Giuliano does not seem to have had a smooth relationship with the Florentine government. Although he was already a highly esteemed and experienced architect, his activity was subject to constant control and not free from criticism. More than once the Florentine council urged him to raise the walls quickly, expressing doubts about the final result. As if he were an apprentice, he was given technical 
suggestions: "Today the walls of the fortresses have to be low and the moats wide and deep, therefore you should pay attention not to raise the walls so much that they'll have to be reduced later, because it would be a bad and shameful thing for you." Gaye, Carteggio, 2:109-12 (unless otherwise noted, all translations are my own). Moreover, the solution he proposed to stop the collapse of the wall overlooking the river-by sinking two boats loaded with stones-was not approved. Gaye, Carteggio, 2:121-22. Later on, his intention to finish the walls of the bastions with a stone molding, an ornamental rather than functional detail, was viewed as delaying the work. Gaye, Carteggio, 2:125. He also had to defend himself against accusations that he was employing poor-quality lime and bricks. Gaye, Carteggio, 2:127-28. In 1512 the allocation of funds was running out, and Giuliano's monthly salary was arbitrarily reduced. The whole program of the fortress had to be redimensioned and the number of workers reduced. A letter dated 11 August refers to a "Maestro Lionardo" arriving at Pisa carrying drawings discussed with the council. Gaye, Carteggio, 2:134.

11. The date could be shifted back one year at most, to 1510 , because, as the history of maps has taught us, authors very often anticipated works when they were acquainted with planned projects for urban transformations. The bastion was demolished in 1781, when the fortress was divested and sold to a private owner. Some remains are still visible in the back of the residential building that took its place and in the riverbank wall. See $L a$ fortezza di Pisa, 51-52.

12. Tolaini, Forma Pisarum, 94-95.

13. Taccuino senese, S.IV.8, Biblioteca degli Intronati, Siena: the cathedral and the Leaning Tower, fol. 30; the baptistery, fol. 27; the fortress, fol. 3v. The sketchbook has been published in a complete facsimile edition: Il taccuino senese di Giuliano da San Gallo: 50 facsimili di disegni d'architettura, scultura ed arte applicata, pub. Rodolfo Falb (Siena: Stabilimento fotolitografico del cav. Luigi Marzocchi, 1899). The drawing labeled "Citadela di Pisa cioè la nova" (The citadel of Pisa, that is the new one) shows a tri-bastion fortress on the other side of the bridge; this fortress was never built.

14. This bastion was also never built.

15. Gaye, Carteggio, 2:109.

16. The drawings in the collection were probably available as studio material and also as model books to be copied by other artists. The mutual exchanges with the Codex Escurialensis, belonging to Ghirlandaio's workshop, have been dated to 1492-93 and are demonstrated in Cristiano Huelsen, Il libro di Giuliano da Sangallo, Codice Vaticano Barberiniano Latino 4424, complete facsimile ed. (1910; anastatic repr., Vatican City: Biblioteca Apostolica Vaticana, 1984), xxxi-xxxiv.

17. This drawing was published in Giorgio Vasari il giovane, La città ideale: Piante di chiese, Palazzi e Ville di Toscana e d'Italia, ed. Virginia Stefanelli (Rome: Officina, 1970), 226. The derivation is undoubtable, because Vasari's drawing reproduces faithfully the arrangement of square, church, and buildings invented by Giuliano, which did not correspond to the real situation. See also note 38 .

18. See Pasquale Nerino Ferri, "La raccolta Geymüller-Campello recentemente acquistata dallo stato per la R. Galleria degli Uffizi," Bollettino d'arte 2, no.1 (1908), 47-65. A complete description and discussion of the three-volume collection is in Plöder, Bramante e gli altri. For a first survey of the collection, see Heinrich von Geymüller, "Documents inedits sur les manuscrits et les oeuvres d'architecture de la famille des Sangallo ainsi que sur plusieurs monuments de l'Italie," Memoires de la Société Nationale des Antiquaires de France (I), series 5, 5 (1885), 222-52.

19. The most ancient nucleus of the remains dates back to the end of the first century. Since the Middle Ages, however, the site has been popularly related to Nero. For a full account, see Marinella Pasquinucci and Simonetta Menchelli, eds., Pisa: Le terme "di Nerone" (Pontedera: Bandecchi e Vivaldi, 1989), 24-26.
20. The interest of this ancient edifice is even stronger given the fact that the same complex was possibly admired by Filippo Brunelleschi when he lived in Pisa as a military engineer, and it might have offered suggestions to him. See ibid., 86-87.

21. It was described as such in a letter written by Francesco Robortello, professor in the Studio of Pisa. See Donatella Alessi, "Ricerche e studi dal XIII secolo alla fine dell'Ottocento," in Pasquinucci and Menchelli, Pisa, 31 .

22. Giuliano used the same process of regularization into rectangular form and axial symmetry in a drawing of a smaller complex of baths at Cimiez, in southern France, in Taccuino Senese, fol. 13r. See Borsi, Giuliano da Sangallo, 264-65.

23. Geymüller, the last private owner of the plan, is the only one to connect the representation of the baths with the project for San Pietro, but he interprets it first as a project for a church, the central piers of which show the influence of Bramante. See Geymüller, Les projets primitifs, 285-87.

24. Gabinetto Disegni e Stampe, 9 Ar, Uffizi, Florence. See Christoph Luitpold Frommel, "2.15.1. Pianta per San Pietro," in Raffaello architetto, ed. Christoph Luitpold Frommel, Stefano Ray, and Manfredo Tafuri (Milan: Electa, 1984), 257; Borsi, Giuliano da Sangallo, 435.

25. Gabinetto Disegni e Stampe, 7 Ar, Uffizi, Florence. The drawing has been dated to Giuliano's first period of collaboration with Bramante, in the first months of 1514, before Bramante's death. See Christoph Luitpold Frommel, "2.15.2. Pianta per San Pietro," in Frommel et al., Raffaello architetto, 257; Borsi, Giuliano da Sangallo, 435.

26. Borsi, Giuliano da Sangallo, 437.

27. The subject of the city plan in the Renaissance was first discussed in John A. Pinto, "Origins and Development of the Ichnographic City Plan," 7SAH 35, no. 1 (Mar. 1976), 35-50. The term ichnographic plan is redundant, however, because the word plan, meaning a bidimensional representation of the horizontal arrangement of a building as a horizontal section, contains the concept of the ichnographic, since it is the equivalent of ichnographia, a Greek term that the ancient architect Vitruvius used to denote a ground plan. Vitruvius, De architectura, I, II.

28. See Lucia Nuti, Ritratti di città: Visione e memoria tra Medioevo e Settecento (Venice: Marsilio, 1996), 118.

29. For discussion of the development of the concept and techniques of the urban survey in the fifteenth and sixteenth centuries, see Jessica Maier, "Mapping Past and Present: Leonardo Bufalini's Plan of Rome, 1551," Imago Mundi 59 (2007), 5-9.

30. Leonardo's plan has been widely reproduced and commented on. For analysis of the plan in relation to surveying methods, see Mario Docci, "I rilievi di Leonardo da Vinci per la redazione della pianta di Imola," in Saggi in onore di Guglielmo De Angelis d'Ossat, ed. Sandro Benedetti and Gustavo Miarelli Mariani (Rome: Multigrafica Editrice, 1987); Ballon and Friedman, "Portraying the City," 681-83; Maier, "Mapping Past and Present," 11-13. Prisciani's plan of Ferrara was included in a manuscript work aimed at celebrating the history of the city. See Marco Folin, "La Proportionabilis et commensurata designatio urbis Ferrariae di Pellegrino Prisciani (14941495)," in Folin, Rappresentare la città, 99-120.

31. In the opening years of the sixteenth century the major innovation in surveying instruments, described in Raphael's letter, was a magnetic compass set at the center of a graduated disk to which a pivoting radial arm was affixed. This instrument allowed the surveyor to fix the bearings of specific points.

32. The only other occurrence of this mark in Giuliano's production can be found in the drawing concerning the Temple of Augustus at Pozzuoli, where it is used to highlight the junctions in the marble blocks of the basement between the columns. In this instance, however, the suggestion of interpreting it as a junction mark is bound to remain a dead end. See the Temple of Augustus at Pozzuoli, Cod. Barb. 4424, fol. 6v. For the codex, 
see Huelsen, Il libro. The drawing is commented on in Borsi, Giuliano da Sangallo, 261-64.

33. A direct comparison is offered by the surveys commissioned by the Grand Duke Cosimo I Medici, who longed for visual knowledge of the major fortresses. The military engineer Giovan Battista Belluzzi surveyed Pisa and the new citadel in approximately 1552. Magl. II, I, 280, fol. 7 (the fortress), fol. 8 (the city), Biblioteca Nazionale, Florence. See the detailed study in Daniela Lamberini, Il Sanmarino: Giovan Battista Belluzzi, architetto militare e trattatista del Cinquecento (Florence: Olschki, 2007), 1:166-70.

34. Tolaini presents an in-depth analysis to verify in detail the correspondence between the drawing and real topography. Tolaini, Forma Pisarum, $72-95$.

35. As a military engineer, Giuliano also had to make inspections of the old citadel, although the signoria had decided to suspend any activity there. See Gaye, Carteggio, 2:120.

36. The Dominican friars wanted to expand their church with two side naves. The work started in 1336 but was soon interrupted due to the terrible plague of 1348 .

37. Cod. Barb., fol. 14; Taccuino senese, fol. $5 \mathrm{r}$.

38. In 1595 Andrea Sandrini, engineer of the Ufficio dei Fossi, was commissioned to draft a plan in order to settle a dispute; that document clearly corroborates the correct position of the church in the square. Fiumi e Fossi, 155, fol. 73v, Archivio di Stato, Pisa.

39. Quotations concerning the Baptistery of Florence from historians and writers such as Fazio degli Uberti, Dante Alighieri, Goro Dati, and Giovanni Villani appear in Borsi, Giuliano da Sangallo, 178-81. Doubts about the monument's origins started to be raised only in the first half of the sixteenth century, but at the end of that century Vincenzo Borghini still considered it a temple. See Zygmunt Waźbiński, "Le polemiche intorno al Battistero fiorentino nel Cinquecento," in Filippo Brunelleschi: La sua opera e il suo tempo (Florence: Centro Di, 1980), 2:933-50.

40. Cod. Barb., fol. 33v. The drawing is commented on in Borsi, Giuliano da Sangallo, 178-81.

41. This document, dated 14 August 1489, is in Conventi soppressi, CXXII, S. Spirito, vol. 128, fol. 99, Archivio di Stato, Florence. See Carlo Botto, "L'edificazione della chiesa di Santo Spirito a Firenze," part 2, Rivista d'arte 13 (1932), 23-24; Mary Hollingsworth, "The Architect in Fifteenth-Century Florence," Art History 7, no. 4 (1984), 404.

42. Botto is inclined to value the Florentine components; see Botto, "L'edificazione della chiesa," 45-46. The Roman ones are stressed by Huelsen, Il libro; and David Hemsoll, "Giuliano da Sangallo and the New Renaissance of Lorenzo de' Medici," in The Early Medici and Their Artists, ed. Francis Ames-Lewis (London: Birkbeck College, University of London, Department of History of Art, 1995), 187-205.

43. Gabinetto Disegni e Stampe, 7816 A, Uffizi, Florence. This drawing is commented on in Plöder, Bramante e gli altri, 144-46.

44. The Baths of Viterbo are now called the Terme del Bacucco; the site is in the Roman region, on the Cassia road from Florence to Rome. Taccuino senese, fol. 8r. Giuliano drew an octagonal interior in a square shell, opened by four entrances on the straight sides and four apses on the oblique ones. Each apse is articulated in three niches. In the center there is a circle, which has been interpreted as a pool. In addition to the plan, another sketch shows the elevation and the umbrella vault that covered the room. Giuliano called it "a temple that is used as a bath," acknowledging its then-current use but following the common misconstruction of its original sacred purpose. See the description in Borsi, Giuliano da Sangallo, 259-61. The Studio of Varro is located at San Germano near Monte Cassino, on the road from Rome to Naples, where the ruins of the Roman town Casinum were spread over the slopes. Cod. Barb., fol. 8r. Giuliano, leaning on classical sources, interpreted this hall as the studio of Varro's villa, as his label says: "Studio of Marcus Varro all worked in stucco braccia VI high and then the barrel vault starts." He reshaped this drawing at different times. At first he drafted only the octagonal structure with four corner apses; on a second occasion he added the four rectangular protruding entrances that transform the edifice into a Greek cross; later, when the sheet was extended by strips of parchment, he completed their ends, partially overlapping the adjacent plan. See the descriptions in Huelsen, Il libro, 15; Borsi, Giuliano da Sangallo, 71-75. The Temple of Apollo is located on the eastern shore of Lake Averno. Cod. Barb. fol. 8v. The sketch plan at top of the sheet shows an internal circular wall widened by four apses, enclosed by an octagonal shell. The drawing is labeled "Temple of Cumaean Sibyl. Eight lights." See the descriptions in Huelsen, Il libro, 16; Borsi, Giuliano da Sangallo, 78-80.

45. The Baths of Viterbo, regarded as a calidarium and sudatorium, are in poor condition today. The umbrella vault has collapsed. Recent reports describe the central pool as polygonal, sixteen sides with steps all around. For the archaeological account, see Costantino Zei, "Le terme romane di Viterbo," Bollettino d'arte 11 (1917), 166; Luigi Catalano, Le terme di Viterbo ai tempi etruschi e romani (Viterbo: Tip. Unione, 1938); Gian Francesco Gamurrini, ed., Carta archeologica d'Italia, 1881-1897: Materiali per l'Etruria e la Sabina, ed. Gian Francesco Gamurrini (Florence: Olschki, 1972).

46. The Greek cross of Varro's villa, although reproduced in many copies, appears to be a fanciful construction unlike the existing remains. Only one entrance leads to the room, as Francesco di Giorgio drew it, labeling it vestibolo. The octagonal edifice is now regarded as a calidarium or a laconicum of the private bath of the villa. The fourth apse was not present in the original building, where a pillar was built for sustaining the vault. Apparently it was transformed into a chapel during the Middle Ages and subsequently abandoned. For the archaeological account see Gian Filippo Carettoni, Casinum (presso Cassino): Regio I, Latium et Campania (Rome: Istituto di Studi Romani, 1940).

47. The Temple of the Sybil is a very big rotunda, only slightly smaller than the Pantheon, now regarded as a swimming pool. Today it is marked by various foundations of vaulted rooms, which collapsed after the volcanic eruption of 1538. For the archaeological account, see Paolo Antonio Paoli, Avanzi delle antichità esistenti a Pozzuoli Cuma e Baia Antiquitatum Puteolis Cumis Baiis existentium reliquiae ([Florence/Naples?], 1768).

48. In the sixteenth century Lorenzo Donati recorded the Baths of Viterbo as octagonal and included the hall in a square courtyard, surrounded by small rectangular rooms. Raffaello da Montelupo's and Giorgio Vasari the younger's drawings are limited to the octagonal hall, in which the internal articulation of the apses is enhanced. It is included in a square exterior shell, and the central pool is rendered as big and rectangular, in such a way that the square dimension of the edifice is stressed. Raffaello da Montelupo's drawing (ca. 1535-40), wrongly attributed to Michelangelo Buonarroti in the past, is in Livre de dessin de Michel-Ange, n.792, Palais des Beaux-Arts, Lille, France. See Barbara Brejon de Lavergnée, ed., Catalogue des dessins italiens: Collections du Palais des beaux-arts de Lille (Paris: Réunion des Musées Nationaux, 1997), 316.

49. Francesco di Giorgio's drawing of the Temple of the Sybil is in Gabinetto Disegni e Stampe, 329 Ar, Uffizi, Florence. See Christoffer H. Ericsson, Roman Architecture Expressed in Sketches by Giorgio Martini: Studies in Imperial Roman and Early Christian Arcbitecture (Helsinki: Societas Scentiarum Fennica, 1980), 108-13; Howard Burns, "XX.20," in Francesco di Giorgio architetto, ed. Francesco Paolo Fiore and Manfredo Tafuri (Milan: Electa, 1994), 342-43. Another sketch by Giuliano's hand is in Gabinetto Disegni e Stampe, 2045/A, Uffizi, Florence. Francesco di Giorgio's drawing of Varro's studio is in Gabinetto Disegni e Stampe, 322 Ar, Uffizi, Florence. See also Ericsson, Roman Architecture, 77-80; Howard Burns, "XX.10," in Fiore and Tafuri, Francesco di Giorgio, 336-37. On the subject of the atrium, see Linda Pellecchia, "Architects Read Vitruvius: 
Renaissance Interpretations of the Atrium of the Ancient House," 7SAH 51, no. 4 (Dec. 1992), 398-99.

50. The admission that invention affected at least one plan of an ancient monument concerns specifically Francesco di Giorgio, Trattati, I, 282, pl. 151 (fol. 82r). See also Ericsson, Roman Architecture, 63; Pellecchia, "Architects Read Vitruvius," 399-400.

51. Beverly Louise Brown and Diana E. E. Kleiner, "Giuliano da Sangallo's Drawings after Ciriaco d'Ancona: Transformations of Greek and Roman Antiquities in Athens," FSAH 42, no. 4 (Dec. 1983), 321-35. Wolfgang Lotz also regards variations in the way Giuliano renders architectural interiors in the sketchbooks as not accidental. See Wolfgang Lotz, Studies in Italian Renaissance Arcbitecture (Cambridge, Mass.: MIT Press, 1977), 18-19.

52. Maier, "Mapping Past and Present," 13-16.

53. Francesco's drawing process has been discussed by Thomas Buddensieg, "Criticism and Praise of the Pantheon in the Middle Ages and the Renaissance," in Classical Influences on European Culture A.D. 500-1500: Proceedings of an International Conference Held at King's College, ed. Robert Ralph Bolgar (Cambridge: Cambridge University Press, 1971), 263-64; Howard Burns, "Quattrocento Architecture and the Antique: Some Problems," in Bolgar, Classical Influences on European Culture, 274-75.

54. On the typologies of the sketchbooks, see Arnold Nesselrath, "I libri di disegni di antichità: Tentativo di una tipologia," in Memoria dell'antico dell'arte italiana, vol. 3, Dalla tradizione all'archeologia, ed. Salvatore Settis (Turin: Einaudi, 1986), 127-29.

55. The issue of the relationship between Giuliano's reconstructions and his own designs is discussed in regard to a particular case in Cammy Brothers, "Reconstruction as Design: Giuliano da Sangallo and the 'Palazo di Mecenate' on the Quirinal Hill," Annali di architettura 14 (2002), 55-72.

56. Codex Escurialensis, fol. 74, Madrid. See Huelsen, Il libro, xxxi-xxxii. See also Nesselrath, I libri di disegni, 130-31.

57. In fact, three different drafts of the plan survive: the rough sketch in the Taccuino senese, fol. 17v; the more accurate, probably the original, drawing of Cod. Barb., fol. 8v; and another detailed drawing in the same codex (at fol. 39v dated very late, possibly 1513) that appears to be a reelaboration after the artist's studies of the Roman baths complexes. The sketch shows only the compartments of the plan. The first solution for the chapel is based on the combination of a square compartment, an octagon inscribed in it, and a circular interior space articulated in eight alternating expansions, four apses in the diagonals and four rectangular niches in the orthogonals. It is a solution close to the Temple of the Sybil, which appears above on the same sheet and on which the drawing of the palace partially overlaps. In the second solution, a more elaborated sequence stands at the top among the arrangement of square rooms: the chapel, connected with the rectangular salone, opens up within a square shell an octagonal space, expanded by the alternation of semicircular and rectangular niches. It closely resembles the Baths of Viterbo. See the descriptions in Huelsen, Il libro, 16, 56; Borsi, Giuliano da Sangallo, 395-404; Hartmut Biermann, "Das Palastmodell Giuliano da Sangallos für Ferdinand I., König von Neapel," Wiener Fabrbuch für Kunstgescbichte 23 (1970), 154-95; Hartmut Biermann and Elmar Worgull, "Das Palastmodell Giuliano da Sangallos für Ferdinand I., König von Neapel: Versuch einer Rekonstruktion," Jahrbuch der Berliner Museen 21 (1979), 91-118; Sabine Frommel, "Lorenzo il Magnifico, Giuliano da Sangallo e due progetti per le ville del Codice Barberiniano," in $I l$ principe architetto, ed. Arturo Calzona (Florence: Sansoni, 2002), 448-50 and the most recent Bianca De Divitiis, "Giuliano da Sangallo in the Kingdom of Naples: Architecture and Cultural Exchange," FSAH 74, no. 2 (June 2015), 152-78.

58. The whole design is based on the square, divided in smaller square rooms distributed around a central compartment whose interior is shaped like an octagon opened in four entrances on the straight sides and four apses on the oblique ones. Again, the closest connection is with the Baths of Viterbo. The relational function and the location however is reminiscent of the ideas expressed both graphically and textually by Francesco di Giorgio in his Trattato, when he is concerned with the atrium, or the ridutto, of a villa for the signori, the upper class. On the subject see Pellecchia, "Architects Read Vitruvius," 398-99. The project has no relationship with Sangallo's actual activity, nor is it explained by documents. The initials $\mathrm{M}^{\circ} \mathrm{L}$ appear, suggesting that it was connected in some way with Lorenzo. It has been supposed that it was a different and more modest version for the palace elaborated for the king of Naples or, more likely, an abstract design, an architectural exercise on the theme of the villa "all'antica," learned from Alberti's treatise and discussed with his patron. Cod. Barb., fol. 9r; Taccuino senese, fol. 17. See Huelsen, Il libro, 16; Borsi, Giuliano da Sangallo, 404-9; Frommel, "Lorenzo il Magnifico," 428-45.

59. The plan undoubtedly referred to a church because the main altar is recorded and in a side room an inscription says "sacristy." Cod. Barb., fol. 61r; Borsi, Giuliano da Sangallo, 430-31; Huelsen, Il libro, 60; Vasari, La città ideale, 213. Enzo Bentivoglio has proposed that it should be interpreted as a design for San Giovanni dei Fiorentini in Rome, the Florentine nation's church, another occasion in which the model of the Baptistery of San Giovanni was influential. See Enzo Bentivoglio, "Disegni nel 'libro' di Giuliano da Sangallo, collegabili a progetti per il S. Giovanni dei Fiorentini a Roma," Mitteilungen des Kunsthistorischen Institutes in Florenz 19, no. 2 (1975), 251-60.

60. Marchini, Giuliano da Sangallo, 63.

61. Gaye, Carteggio, 1:194. In a letter dated 13 March 1460, there is explicit reference to a disegno of the fortress brought by "Maestro Antonio Manetti."

62. Gaye, Carteggio, 2:112.

63. As the title for his major studio book, Giuliano himself wrote the word libro (a bound collection of sheets) followed by the description "con disegni mesurati e tratti dall'antico" (including drawings measured and drawn from antiquity). 